\title{
ECONOMIC ASSESSMENT OF POLYMER CONCRETE USAGE IN GEOTHERMAL POWER PLANTS
}

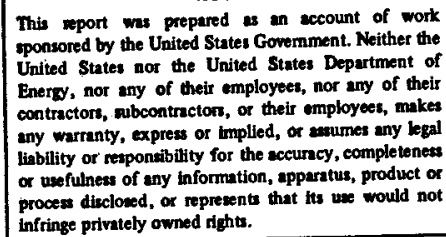

November 1977

Prepared by

Burns \& Roe Industrial Services Corporation

Paramus, New Jersey

Under BNL Contract No. 417259-S

for the

PROCESS SCIENCES DIVISION

DEPARTMENT OF ENERGY \& ENVIRONMENT

BROOKHAVEN NATIONAL LABORATORY

UPTON, NEW YORK 11973 


\section{DISCLAIMER}

This report was prepared as an account of work sponsored by an agency of the United States Government. Neither the United States Government nor any agency Thereof, nor any of their employees, makes any warranty, express or implied, or assumes any legal liability or responsibility for the accuracy, completeness, or usefulness of any information, apparatus, product, or process disclosed, or represents that its use would not infringe privately owned rights. Reference herein to any specific commercial product, process, or service by trade name, trademark, manufacturer, or otherwise does not necessarily constitute or imply its endorsement, recommendation, or favoring by the United States Government or any agency thereof. The views and opinions of authors expressed herein do not necessarily state or reflect those of the United States Government or any agency thereof. 


\section{DISCLAIMER}

Portions of this document may be illegible in electronic image products. Images are produced from the best available original document. 


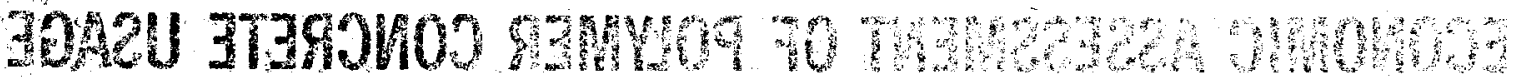

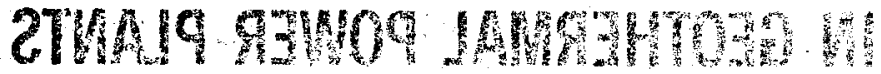

This report was prepared as an account of work sponsored by the United States Government. Neither the United States nor the United States Department of Energy (DOE), nor any of their employees, nor any of their contractors, subcontractors, or their employees, makes any warranty, express or implied, or assumes any legal liability or responsibility for the accuracy, completeness or usefulness of any information,

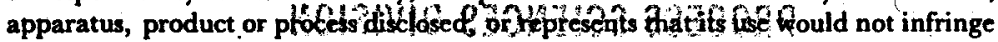

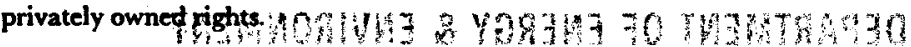

Printed in the United States of America Available from

National Technical Information Service

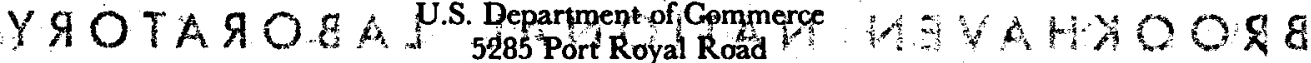

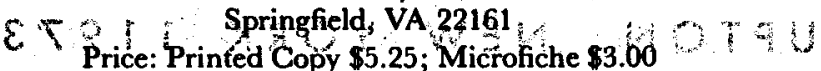




\section{CONTENTS}

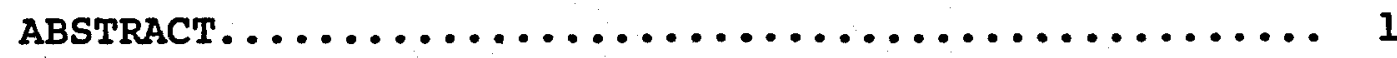

INTRODUCTION......................... 2

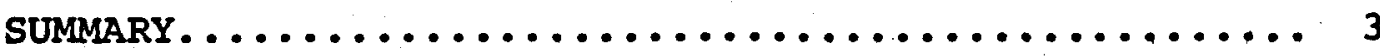

concLusions........................... 6

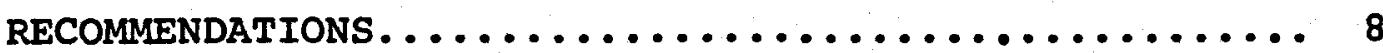

MATERIAL ASSESSMENT AND DEVELOPMENT NEEDS........ 10

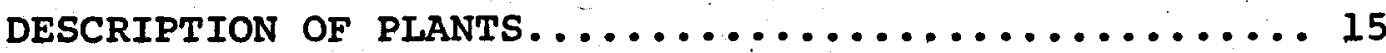

Heber Geothermal Brine Power Generation........ 15

Process Description................ 15

Equipment Description.............. 17

Niland Geothermal Brine Power Generation....... 24

Process Description................ 24

Equipment Description.............. 27

PROCEDURES.......................... 34

RESULTS OF STUDY.................... 37

Heber Plant.............................. 37

Niland Plant...................... 42

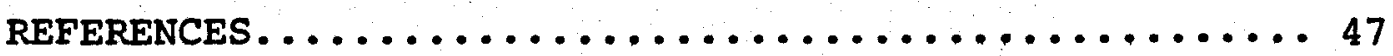




\section{ABSTRACT}

The objective of this report was to review the Heber and Niland, California 50 MWe conceptual geothermal power plants designs and to identify areas where non-metaliic materials, such as polymer concrete, can be technically and economically employed. Emphasis was d irected toward determining potential economic advantages and resulting improvements in plant availability. It is estimated that use of polymer concrete in the Heber plant will effect a savings of $6.18 \mathrm{mills}$ per $\mathrm{KWH}$ in the cost of power delivered to the network, a savings of $9.7 \%$. A similar savings should be effected in the Niland plant. 


\section{INTRODUCTION}

Burns and Roe Industrial Services Corporation agreed to provide engineering assistance for the evaluation, review and identification of materials which may be technically and economically used in critical service areas of existing geothermal prócess.

The agreed upon scope of work was:

1. Review and evaluate ERDA report, dated october 1976, on "Conceptual Design of Commercial 50 MWe (net) Geothermal Power Plants at Heber and Niland, California". Determine the critical services and the materials that are specified for both geothermal sites.

2. Identify areas where non-metallic materials such as polymers, concrete polymer components, refactory or other alternate metallic or semimetallic materials can be technically and economically employed on both geothermal sites.

3. Perform economic studies to determine the potential economic advantages of employing the alternate materials in the services defined above. The improvement in plant availability from longer service life alternate materials, and/or future replacement costs should be studied.

4. Summarize the results in a report to Department of Energy - Division of Geothermal Energy through Brookhaven National Laboratory. The report will include all study data and summarize the cost impact of alternate materials on the two 50-MWe (net) conceptual geothermal power plants at Heber and Niland, California. 
A research program to develop polymer concrete composite materials having qualities superior to those of Portland cement concrete as materials of construction has been a continuing effort of the process sciences Division of the Department of Energy and Environment (Formerly Department of Applied Science) of Brookhaven National Laboratory and at other Federal Agencies.

As a part of this effort, Burns and Roe Industrial Services Corporation has been engaged to study the cost effectiveness of these materials in electric power generating facilities designed to use geothermal sources of energy.

The Bechtel Corporation had previously performed conceptual designs for typ 50-MWe (net) power plants operating on geothermal brines 1 .

One plant utilized a moderate-temperature, low-salinity brine as produced near Heber, California, in the Imperial Valley, and the other utilized a high-temperature, highsalinity brine as produced near Niland, California, also in the Imperial Valley, near the Salton Sea.

In both plants extensive use was made of carbon steel for vessels and piping, with Type $316 \mathrm{~L}$ stainless steel or titanium utilized only where carbon steel was considered to be unsuitable.

Each design was carried out in sufficient detail to obtain an estimate of plant capital cost.

The design of the Heber plant was based upon direct, two-stage flashing of the geothermal brine, with the flashed steam being used to drive a tandem-compound, dual-admission turbo-generator. The expanded steam leaving the lowest pressure stage was condensed by direct contact with circulating cooling water. The enriched brine was reinjected into the underground reservoir formation.

The Niland plant design, was based on a multi-stage, multiple-flash design, to acquire the maximum amount of heating steam from the brine. Isopentane was circulated through the stages under supercritical conditions with the flashed steam being condensed by the isopentane and returned to the brine in such a manner that the composition of the brine remained unchanged throughout the plant. The isopentane vapors leaving the hottest flash stage were used to power the turbo-generator, with the exit low-pressure isopentane 
vapors being condensed by circulating cooling water. Makeup to the cooling tower was brackish water obtained from the nearby New River. All of the original brine leaving the plant was reinjected into the underground reservoir formation, as was the cooling tower blowdown.

Burns and Roe Industrial Services corporation (BRISC) reviewed the two designs with the view of substituting in as far as possible polymeric materials for the metals used by Bechtel. BRISC has treated the designs of the two plants separately and has prepared estimates of cost savings which can be made in the capital cost of the two plants by use of polymeric materials.

These capital cost estimates covered the battery limits plants as presented in the original report. In addition, Burns and Roe estimated brine supply and reinjection piping costs as delineated in the report for the Heber Plant. No estimate of this piping was included for the Niland plant due to the limited amount of detail provided in the original report.

Savings can be effected in the construction cost of each of these plants. In the case of the Heber plant, it has been shown that a savings of $\$ 881,074$ can be had, based on the equipment and lines within the battery limits and $\$ 2,857,725$ for brine supply and brine reinjection lines outside the battery limits. In the Niland case we have shown a $\$ 553,741$ savings for equipment and lines within the battery limits. No estimate of savings has been made for the off-battery-limits piping. These savings have been estimated using data developed by procedures detailed in the body of this report.

These savings in capital cost have a direct impact on the cost of electric power and will result in a reduction in costs of 2.72 mills per kilowatt hour for the Heber plant. A similar savings is anticipated for the Niland plant.

Limited data are available on which a proper comparison of service life or maintenance costs can be made for materials operating in geothermal brine environments.

Hot brine and other aerated geothermal fluids are highly corrosive materials that attack conventional materials of construction. BRISC experience in the design and operation of desalination plants using conventional materials has shown us that the corrosion rate of carbon steel by hot, saline waters is high ( $10 \mathrm{mpy}, 0.25 \mathrm{~mm} / \mathrm{yr}$ ) even following efficient deaeration of the water. Severe corrosion of carbon steel occurs in aerated geothermal fluids, 
with reported values 100 times greater than in oxygen-free waters. The structural integrity of the steels must be preserved by the use of large corrosion allowances, by use of impervious surface coatings or by the use of molybdenumbearing, austenitic stainless steels (Type $316 \mathrm{~L}$ ) or more resistant metals. All of these alternatives increase the cost of the equipment.

Polymer concrete, made with properly selected monomers, can protect carbon steel surfaces from corrosion at temperatures above the expected geothermal operating range and preserve structural integrity without the use of large corrosion allowances or of other surface coatings. Polymer concrete coatings are useable over a much wider range of $\mathrm{pH}$ than commonly used ceramic coatings. Good durability was indicated in laboratory tests when polymer concrete was expgsed to 258 brine at $3592^{\circ}$ ( $\left.177^{\circ} \mathrm{C}\right)$ for 601 days, and $460^{\circ} \mathrm{F}\left(238^{\circ} \mathrm{C}\right)$ for 200 days $(2)$ Also, when exposed to $\mathrm{pH} 1$ HCl solution at $194^{\circ} \mathrm{F}\left(90^{\circ} \mathrm{C}\right)$ for $419^{\prime}$ days no deterioration was seen ${ }^{(3)}$ ?

Further experimental work is in progress in the field in which polymer concrete and polymer concrete-coated surfaces are being exposed to geothermal waters at operating temperatures and pressures. The preliminary results from field exposures of up to two years indicate that excellent service life may be expected for several of these compositions. The use of polymer concrete material should markedly reduce corrosion problems in both piping and vessels.

As a result, it is anticipated that the use of polymer concrete will allow the availability of the plant to increase from the 708 estimated by Bechtel to $74 \%$. This is equivalent to a reduction of 3.46 mills per kilowatt hour. The overall savings in the cost of electricity resulting from the reduction in capital costs and increase in plant availability is $6.18 \mathrm{mills}$ per kilowatt hour at the Heber plant. A similar savings is anticipated for Niland plant. 


\section{CONCLUSIONS}

1. Polymer concrete may be used in the design of geothermal or saline water facilities to counter corrosion at temperatures up to $460^{\circ} \mathrm{F}\left(238^{\circ} \mathrm{C}\right)$.

2. The cost of polymer concrete coatings in most cases is less than other alternate methods of providing corrosion protection.

3. For both the Heber and Niland conceptual designs, plants using polymer concrete coatings for vessels and piping were estimated to cost less than plants using conventional materials of construction.

4. Material costs for vessels and piping within the Heber plant battery limits were reduced by 808 and 298 , respectively, resulting in an average of 448 through the use of polymer concrete linings. This amounts to a total savings in capital costs $\$ 881,074$.

5. Brine supply and reinjection piping material costs for the Heber plant were reduced by $40 \%$ or $\$ 2,857,725$.

6. Total savings of $\$ 3,739,000$ for the Heber Plant results in a reduction in the cost of electric power production of 2.72 mills per kilowatt hour.

7. Material costs for vessels and piping within the Niland plant battery limits were reduced by $\$ 554,000$, which is 358 .

8. Polymer concrete, applied to carbon steel vessels by the techniques usually used with concrete linings is cheaper than the 3/4-inch $(19 \mathrm{~mm})$ corrosion allowance provided in designing these vessels. Polymer concrete applied $1 / 2$ inch. $(13 \mathrm{~mm})$ thick inside carbon steel pipes is cheaper than carbon steel pipes with corrosion allowances made by Bechtel.

9. The life expectancy of these plants utilizing polymer concrete is expected to be much longer than those using conventional materials.

10. The on-stream availability of plants using polymer concrete linings for vessels and piping has been estimated to be $4 \%$ greater than plants constructed of carbon steel. 
11. An increase in on-stream availability of 48 for the Heber plant will result in a net cost reduction of 3.46 mills per kilowatt hour produced.

12. The reduction in capital cost and anticipated improvement in on-stream availability effected through the use of polymer concrete construction in the Heber plant will result in an overall saving of $6.18 \mathrm{mills}$ per kilowatt hour produced.

13. Similar savings in capital and operating costs can be predicted for the Niland plant.

14. Hot brine and other aerated geothermal fluids are highly corrosive materials that attack conventional materials of construction. The corrosion rate of carbon steel by hot, saline waters is high, $110 \mathrm{mpy}$, $0.25 \mathrm{~mm} / \mathrm{yr})$, even following efficient deaeration of the water. Severe corrosion of carbon steel occurs in aerated geothermal fluids, with reported values 100 times greater than in oxygen-free geothermal fluids (2) Aerated conditions will occur whenever a plant is opened to allow maintenance operations.

15. Polymer concrete, made with properly selected monomers, can protect carbon steel surfaces to temperatures above the expected geothermal operating range and preserve structural integrity without the use of large corrosion allowances or other surface coatings.

16. Polymer concrete coatings are useable over a much wider range of $\mathrm{pH}$ values than other commonly used coatings.

17. Corrosion by saline water may be countered by the use of molybdenum, austenitic stainless steels (Type 316), or more resistant metals. All of these alternatives increase the cost of equipment. 


\section{RECOMMENDATIONS}

The results obtained from laboratory and initial field tests have demonstrated the suitability of the polymer concrete linings for use in geothermal environments. This study has indicated that the economic potential of polymer concrete linings in geothermal brine service is also very favorable. To provide data which will be necessary before polymer concrete linings can be commercially specified, the following recommendations are offered:

1. In pilot units through the use of coupons, spool pieces and panels, a complete set of mechanical and thermal data for the range of conditions anticipated should be developed including thermal conductivity, strength of bond, expansion coefficients, water permeability and strength properties.

2. Additional spool pieces of polymer concrete lined pipe should be installed at a geothermal field and extensively tested in brines at design velocities and pressures, and at valves and joints where cavitation may be expected or induced.

3. Data on the resistance of polymer concretes to damage from vibration, water hammer, or thermal cycling should be obtained.

4. Resistance of polymer concrete to both acid and mechanical cleaning solutions that may be used for mineral scale removal as well as abrasion resistance to mechanical cleaning equipment such as moles or high pressure jet lances should be determined.

5. Repair procedures for spalled, cracked, chipped or otherwise damaged polymer concrete that can be accomplished in the field and in restricted areas, and possibly under adverse environments should be developed.

6. Procedures should be developed to control the polymer concrete surface finish, to obtain highly polished finishes free of potholes. Tests to monitor changes in surface condition with time are also needed.

7. An effort should be made to develop application procedures whereby the thickness of polymer concrete linings can be reduced to only that required to form an impermeable barrier. 
8. Large-scale or full-size tests should be undertaken of key components to verify and demonstrate information development.

9. An assessment should be made of the economic potential of either prestressed or post-tensioned polymer concrete vessel construction. 
It has long been known that carbon steel exposed to geothermal brines is aggressively attacked and lining the exposed carbon steel with various materials is necessary to withstand this attack. The life expectancy of equipment handling geothermal brines, and therefore the economics of geothermal power, presents a real economic need for use of improved, low cost, materials as coatings for exposed carbon steel surfaces.

Polymer concretes have been identified as promising lining materials. Polymer concrete is a mixture of polymerized organic materials (monomers), with inorganic ingredients similar to those used in Portland cement concrete. These include sand, gravel and other aggregates, plus fillers such as Portland cement or fly ash. The resulting polymer concrete has many properties superior to those made with hydrated Portland cement, Table i. To date, monomer formulations, 60 wto styrene - 40 wtz trimethylolpropane trimethacrylate (TMPTMA) and $50 \mathrm{wt}$ styrene - $33 \mathrm{wt} z$ acrylonitrile - 17 wtz TMPTMA, have been shown to be durable to geothermal fluids ${ }^{(5)}$. These systems can be polymerized using chemical initiators and heat or by chemical initiators and promoters.

Polymer concrete test samples have shown enhanced physical strength coupled with increased resistance to chemical attack by aggressive 258 brine solutions, flashing brine, or dry steam over a wide range of $\mathrm{pH}$ and temperature, with no increase in permeability. As produced, the geothermal brine is characterized by its high saline content, low $\mathrm{pH}$, dissolved carbon dioxide and hydrogen sulfide, and substantial amounts of calcium sulfate, calcium carbonate and silica. These materials, dissolved in water at elevated temperatures, render the brine quite corrosive to many materials of construction and to deposition of solids when the temperature is changed.

A cursory review of the effect of geothermal brines on the more common metals of construction such as carbon steel, which is normally the cheapest material of construction available, shows that the rate of corrosion is a function of $\mathrm{pH}$ and temperature. Corrosion is highest at $\mathrm{pH}$ values in the acid and highly alkaline regions, and minimal in the $\mathrm{pH}$ 5 to $\mathrm{pH} 12$ region. Geothermal brines from the well are uaually on the acidic side of neutral due to the presence of dissolved carbon dioxide and hydrogen sulfide, and even 
TABLE I

PROPERTIES OF CONCRETE-POLYMER MATERIALS

Polymer-Impregnated Concrete

Density

Compressive strength

Tensile strength

Flexure strength

Water absorption

Thermal conductivity

$\begin{array}{ll}150 \mathrm{pcf} & 2.40 \mathrm{gms} / \mathrm{cm}^{3} \\ 20,000 \mathrm{psi} & 138 \mathrm{MPa} \\ 1,600 \mathrm{psi} & 11.0 \mathrm{MPa} \\ 2,000 \mathrm{psi} & 13.8 \mathrm{MPa} \\ <0.5 \% & \\ 1.3 \mathrm{BTU}_{\mathrm{TH}} \mathrm{hr} & 0.0225 \mathrm{Watts} / \mathrm{cm}^{\circ} \mathrm{C} \\ \mathrm{ft} \mathrm{F} & \end{array}$

Lightweight Polymer-Impregneted Concrete

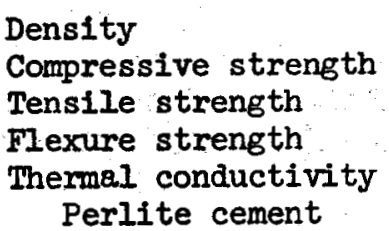

Foamed glass concrete
60-70 pef

5,000 psi

1,000 psi

1,800 psi

$0.11 \mathrm{BTU} / \mathrm{hr}$ $\mathrm{ft}_{\mathrm{F}}$

$0.16 \mathrm{BTU} / \mathrm{hr}$
$34.5 \mathrm{MPa}$

$6.9 \mathrm{MPa}$

12. 4 MPa

0.00190 Watts/cm ${ }^{\circ} \mathrm{C}$

0.00276 Watts $/ \mathrm{cm}^{\circ} \mathrm{C}$

\section{Polymer Concrete}

Density

Compressive strength

Tensile strength

Flexure strength

Water absorption

Thermal conductivity
$140 \mathrm{pcf} \quad 2.24 \mathrm{gms} / \mathrm{cm}^{3}$

12,000 psi

82.7 $\mathrm{MPa}$

1,000 psi

2,000 psi

$6.9 \mathrm{MPa}$

$<1 \%$

$\sim 1, \mathrm{BTU} / \mathrm{hr}$ $\mathrm{ft}^{\mathrm{O}}$ 
though these brines are usually oxygen-free and of a reducing nature, air inleakage must be kept to a.minimum to avoid increases in corrosion rates, as well as deposition of dissolved solids.

In oxygen-poor environments, steel is protected from further corrosion by its initial layer of magnetic oxide $\left(\mathrm{Fe}_{3} \mathrm{O}_{4}\right)$ which is very adherent at moderate temperatures. Breaks in this coating are self-repairing in water containing small amounts of oxygen. Higher oxygen content results in the formation of ferric oxide $\left(\mathrm{Fe}_{2} \mathrm{O}_{3}\right)$ which does not adhere as strongly to the steel and allows continuing corrosion.

The rate of attack of carbon steel is usually taken to be in the range of $10 \mathrm{mils}(0.010 ", 0.25 \mathrm{~mm})$ per year in saline water when the oxygen content is less than $1.0 \mathrm{ppm}$. These rates are greatly enhanced when oxygen is admitted to the system.

In the presence of hydrogen sulfide, even in trace amounts, $\mathrm{Fe}_{3} \mathrm{O}_{4}$ is attacked to form Fes and $\mathrm{FeS}{ }_{2}$ which do not adhere to the steel; this exposes the bare metal to further attack.

BRISC operating experience with such plants indicates that carbon steel equipment functions adequately as long as oxygen is excluded from the system. When oxygen cannot be excluded (as during repair periods), the corrosion rate is greatly increased, being 3 to 10 times greater. Corrosion rates for carbon steels in seawater evaporators operating at temperatures up to $250^{\circ} \mathrm{F}\left(121^{\circ} \mathrm{C}\right)$ using sulfuric acid for scale control have had poor service records. One current practice is to not use carbon steel in contact with saline brine, but to rely on more costly metallic alloy linings or, in some cases, aluminum silicate cement concretes.

Other materials which could be considered for use in geothermal power plants include copper and stainless steel. However, these materials are very $y_{2}$ costly, being on the order of $\$ 15$ to $\$ 25 / \mathrm{ft}^{2}\left(\$ 161\right.$ to $\left.\$ 269 / \mathrm{m}^{2}\right)$.

Copper and its alloys are highly resistant to oxygenated seawater and are widely used in such service. Unfortunately, both copper and its alloys are very susceptible to attack by hydrogen sulfide. The sulfides formed do not adhere to the base metal.

of the various stainless steels, only austenitic (Type 316L) stainless steel resists the attack by hydrogen sulfide 
on wetted surfaces. Type 304 stainless steels are subject to pitting corrosion attack by brines containing chloride ions. When chlorine and oxygen are present, stress corrosion cracking of austenitic stainless steel results. These steels show velocity effects and are not serviceable under high velocity conditions.

Aluminum and most of its alloys are free from attack from $\mathrm{H}_{2} \mathrm{~S}$ and $\mathrm{CO}_{2}$ in the absence of chlorides and are frequently used in such service. However, high chloride ion concentrations cause pitting corrosion. They therefore cannot be depended upon to resist attack by geothermal brines.

Laboratory and preliminary field tests have shown that several polymer concrete formulations are suitable for use in hot saline water applications under widely varying $\mathrm{pH}$ conditions and elevated temperatures. Resistance to corrosion is a function of the monomer and the aggregates used in compounding, and further testing is continuing to determine the optimum.

Testing of polymer concrete mixtures under temperatures in the $150^{\circ}-200^{\circ} \mathrm{C}\left(302-392^{\circ} \mathrm{F}\right)$ range in flowing brines is under way but has not been completed. Such testing is essential to determine the suitability of polymer concrete linings for field collecting and transfer lines for the brine.

Problems of scaling and corrosion, encountered in every geothermal power plant, are a major cause of plant maintenance and necessary repairs that affect plant availability. Corrosion problems most likely will become minimal when using polymer concretes since present field tests indicate negligible corrosion rates for polymer concrete materials.

Currently, limited operating data are available to allow experience comparisons concerning erosion, scaling, plugging, pitting, and/or corrosion. These will all affect plant availability, especially scaling and plugging that may continue even if certain pieces of equipment and lines are polymer concrete lined. The surface appearance of lined polymer concrete piping is hard and glass-like, with some small pockets being visible. Experiments to control this surface effect with varying application procedures may contribute to a lessening of this potential for scale buildup that may eventually end up as a solid plugging mass requiring a plant shutdown for removal. 
Data on the degree of metal surface preparation performed prior to application of the polymer concrete lining, the porosity of the lining and extent of water absorption, even though laboratory tests show very little absorption, and the extent of anchoring used in the lining of large diameter surfaces to avoid possible collapsing of the lining, is limited, and these items should be investigated to provide a complete data base with which to design and specify polymer concrete linings.

It is expected that with the use of polymer concrete lining the influence of the corrosion factor on plant availability will be greatly reduced, so that scaling will remain the primary influence on plant availability.

The need to develop long-term operating data using polymer concrete linings is evident before a fully comparable evaluation can be attempted on service life, repair frequency and maintenance costs. 


\section{DESCRIPTION OF PLANTS}

HEBER GEOTHERMAL BRINE POWER GENERATION

PROCESS DESCRIPTION

In the design of the Heber power facility, hot geothermal brine from 28 wells, located approximately 2 miles from the plant site, was to flow to the plant battery limits through 7000 feet $(2297 \mathrm{~m})$ of 16-inch (406 mm) diameter line at a rate of 12.0 million pounds per hour (5443 tonne/hr) for the generation of 50 MWe (net) electrical power.

Brine was to be received at the plant site boundary in a two-phase state, typically with 14,000 parts per million (ppm) total dissolyed solids, and at a mean downhole temperature of $360^{\circ} \mathrm{F}\left(182^{\circ} \mathrm{C}\right.$. At battery limits, the brine was at a temperature of $338^{\circ} \mathrm{F}\left(170^{\circ} \mathrm{C}\right)$ and a pressure of 115 psia (793kPa). The steam flashed from this brine contained less than one percent by weight of non-condensable gas, which was predominately carbon dioxide with trace amounts of methane, hydrogen sulfide, and ammonia.

Bechtel assumed for the purposes of their study that the properties of the brine supplied to the battery limits, particularly the brine temperature and pressure, would remain constant over the economic life of the plant. Included and of serious concern, was the concentration of scale-forming ions, namely: calcium, barium, strontium, silica, sulfate and bicarbonate.

To suit the economic conditions of the geothermal brine available in the Heber plant area, Bechtel exployed a flashsteam energy conversion process, in which steam was produced from geothermal brine by reducing the pressure of the brine to a point below its vapor pressure. For the Heber plant, Bechtel selected a two-stage process as most economical.

The geothermal brine from the various wells was collected and fed by a $45-$ inch $(1143 \mathrm{~mm})$ main line to the battery limits where four $24-1 \mathrm{nch}(610 \mathrm{~mm})$ diameter lines fed the brine to two horizontal, first-stage flash tanks. The hot brine, at $338^{\circ} \mathrm{F}\left(170^{\circ} \mathrm{C}\right)$ and 115 psia $(793 \mathrm{KPa})$ was admitted to the first-stage flash tanks, where its pressure was reduced to 50.5 psia $(348 \mathrm{KPa})$. A portion of the water content of the brine flashed into steam. The residual brine, from each flash tank flowed into a $30-i n c h(762 \mathrm{~mm})$ diameter line from which two 24-inch (610 mm) diameter lines fed each horizontal, low-pressure, second-stage flash tank. Here its pressure was further reduced to 15.9 psia (110 KPa) at a temperature of $216^{\circ} \mathrm{F}\left(102^{\circ} \mathrm{C}\right)$. The pressure was maintained above atmospheric to eliminate potential corrosion and 
worsening of non-condensable gas problems caused by air inleakage into the low-pressure vessels and related equipment.

The residual brine at $216^{\circ} \mathrm{F}\left(102^{\circ} \mathrm{C}\right)$ from the secondstage flash tanks was piped through 20 -inch $(508 \mathrm{~mm})$ lines. A portion was used to provide the scrubbing liquid for removing hydrogen sulfide from the non-condensable gases before they were vented to the atmosphere. The remainder of the brine was piped through a 40-inch (1016 mm) line to the reinjection pumps. In the first-and second-stage flash tanks 14.68 of the water content of the brine was vaporized.

Steam from both first-and second-stage flash tanks was directly admitted, by 30 -inch $(762 \mathrm{~mm})$ lines into a dualadmission steam turbine which drove an electric generator. Turbine back pressure was maintained at 4-inch Hga 113.5 $\mathrm{KPa}$ ) by condensing the turbine exhaust vapor in a directcontact heat exchanger, $40^{\prime}$ wide by $50^{\prime}$ long by $34^{\prime}$ high $(12.19 \times 15.24 \times 10.36 \mathrm{~m})$. Cooling water was piped through a 60 -inch $(1524 \mathrm{~mm})$ line from a mechanical draft cooling tower. Make-up water for the cooling tower was supplied by the turbine exhaust condensate, thereby eliminating the need for an outside water supply for this purpose.

Non-condensable gases, such as hydrogen sulfide and carbon dioxide, entered the direct-contact heat exchanger with the exhaust steam from the steam turbine. These gases were vented through a 20-inch $(508 \mathrm{~mm})$ line to a two-stage steam jet ejector with inter-and after-condensers. The ejector system was provided to boost the pressure to allow the non-condensables to be vented to the atmosphere. The system was powered by steam taken off the line feeding the steam turbine. An $8^{\prime}(2.44 \mathrm{~m})$ high after-condenser was part of the ejector system to cool the gases and condense the steam. Cooling water to these condensers was obtained from the cooling tower through a 20 -inch $(508 \mathrm{~mm})$ line. The return was to the direct-contact heat exchanger pump by a 40-inch $(1016 \mathrm{~mm})$ diameter line.

The uncondensed gases, mainly hydrogen sulfide and carbon dioxide, passed to an $\mathrm{H}_{2} \mathrm{~S}$ scrubber through a 14-inch $(356 \mathrm{~mm})$ line from the after-condenser. In the scrubber the gases were subjected to countercurrent scrubbing with spent brine from the second-stage flash tank. The brine served to scrub out the hydrogen sulfide and allow the remaining carbon dioxide to be vented to the atmosphere. The rich brine from the scrubber was combined with the brine flowing to the reinjection pumps. 
Spent brine from the second-stage flash tanks was collected by a 40-inch (1016 mm) main line and fed to 3 reinjection pumps. Thirty-two thousand $(32,000)$ feet $(9754 \mathrm{~m})$ of $18-$ inch $(457 \mathrm{~mm})$ diameter line was used to return the water into 14 wells at a pressure of 315 psia (2172 KPa)

A schematic diagram of the process is shown in Figure I and a section through the flash tanks in Figure II.

\section{EQUIPMENT DESCRIPTION}

a. First-Stage Flask Tanks, T-1A and T-1B. The first-stage flash tanks, as designed by Bechtel were horizontal vessels, $11^{\prime}-3^{\prime \prime}$ diameter by $28^{\prime}-0^{\prime \prime}$ long $(3.43 \varnothing \times 8.53 \mathrm{~m})$. The shells were of carbon steel, designed to operate at 75 psia (517 KPa) and $338^{\circ} \mathrm{F}\left(170^{\circ} \mathrm{C}\right)$. As shown in Figure II, the interior of the tanks included a perforated flash pipe from which the brine was ejected through a series of holes along the top of the pipe. A shroud on either side of the pipe constrained the brine jets and a curved impingment plate deflected the two-phase flow downward and towards the sides of the tank. The pipe, shrouds and supports were of titanium, which Bechtel claimed had been shown to withstand erosion from high velocity brine at elevated temperature.

To prevent brine liquid mist carryover with the generated steam, two Type $316 \mathrm{~L}$ stainless steel mist eliminators were suspended full length below the top of the tank. A recirculating stream of fresh wash water provided a rinse for the steam passing through the first mist eliminator. Brine droplets in the steam were separated by the lower high-density eliminator, and any dry salt crystals that might clog the eliminator, were washed off by the fresh water. The water also served to condense any volatile silica compounds or boric acid carried by the steam. The top mist eliminator removed any remaining liquid mist in the outlet steam.

BRISC has estimated the cost of a comparable flash unit using polymer concrete as a material of construction. For the first-stage flash tanks BRISC has determined the shell thickness required by the code . The corrosion allowance used by 


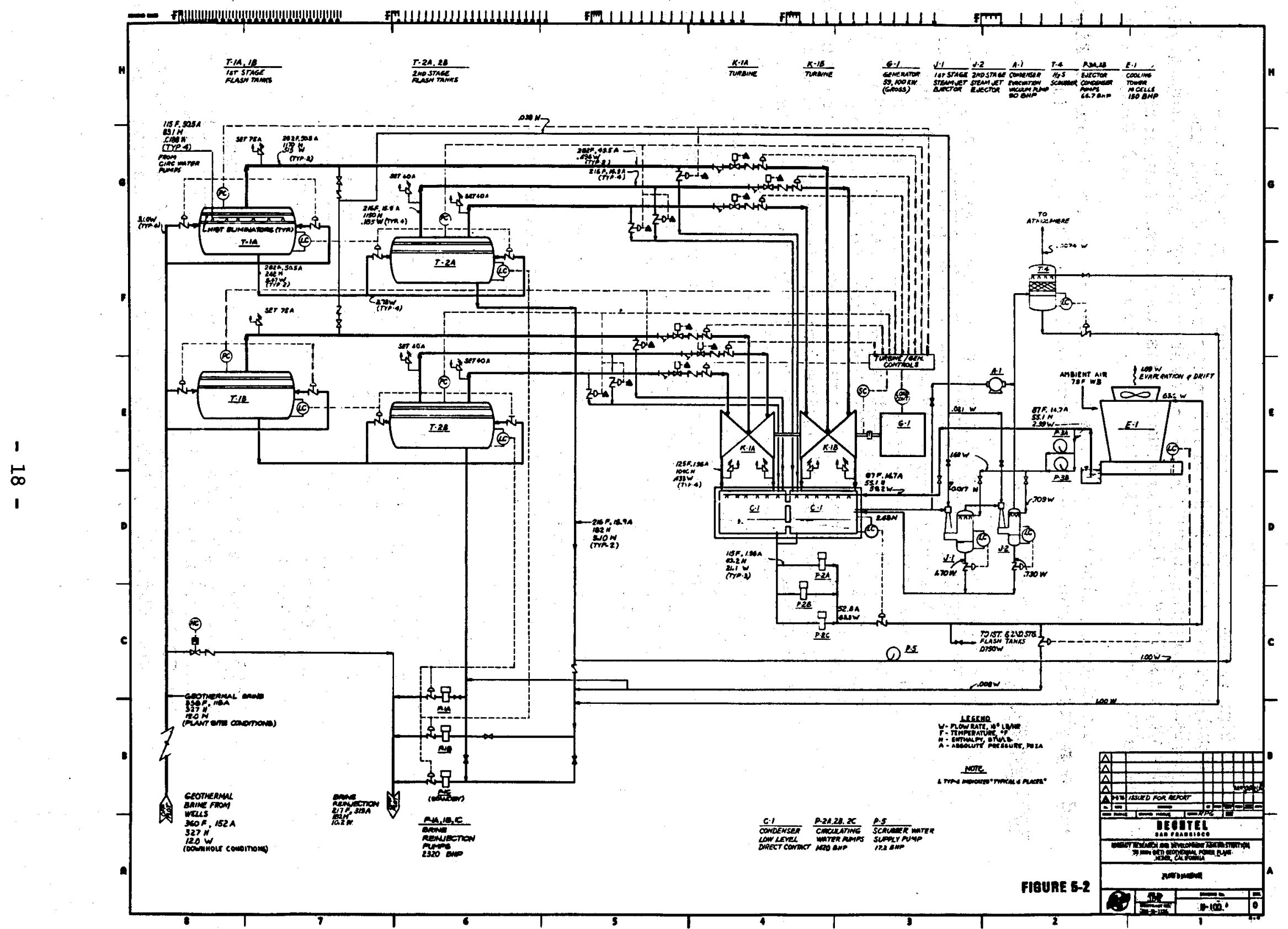

Figure I. 


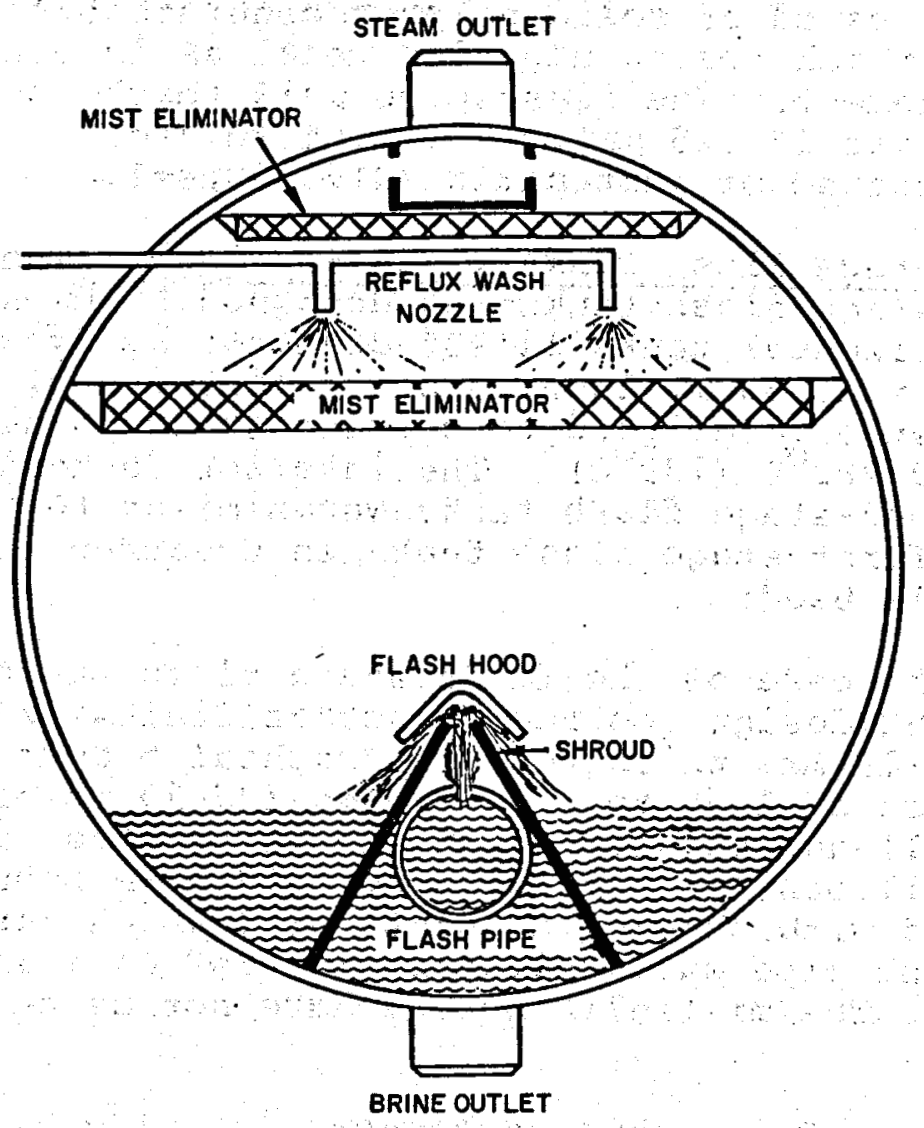

Figure II. Schematic of flash stage for geothermal brine. 
Bechtel was calculated based on this thickness. Polymer concrete $3 / 4^{\prime \prime}(19 \mathrm{~mm})$ thick has been applied to the code-required shell and heads. The flash hood, shrouds, mist deflector and flash pipe are fabricated of solid polymer concrete $3 / 4$ " $(19 \mathrm{~mm})$ thick, using expanded metal as internal reinforcement. The flash pipe wall thickness has been set at $I^{\prime \prime}(25 \mathrm{~mm})$. The mist separators have been retained of austenitic (316L) steel.

b. Second-Stage Flash Tanks, T-2A and T-2B. The second-stage flash tanks, as designed by Bechtel,

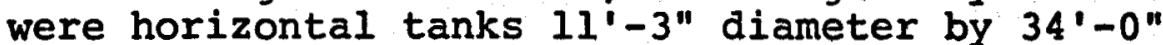
$(3.43 \varnothing \times 10.36 \mathrm{~m})$ long. The shells were of carbon steel, designed to operate at 40 psia (276 $\mathrm{KPa})$ and $282^{\circ} \mathrm{F}\left(139^{\circ} \mathrm{C}\right)$. The interior design of the second-stage flash tanks was similar to that of the first-stage flash tanks in construction and materials used.

As in the case of the first-stage flash tanks, in the BRISC design, polymer concrete lining 3/4inches (19 mm) thick replaces Bechtel's corrosion allowance of 1.50 to 1.70 inches $(38-43 \mathrm{~mm})$ for the shell and heads. As in the first-stage flash tank, all other internal components have been replaced with polymer concrete $3 / 4^{\prime \prime}$ thick $(19 \mathrm{~mm})$. The flash pipe wall thickness is kept at 1 inch $(25 \mathrm{~mm})$. The mist eliminators have not been changed.

c. Condenser, C-l. This condenser, $40^{\prime}$ wide by $52^{\prime}$ Iong and $34^{\prime}$ high $(12.19 \times 15.85 \times 10.36 \mathrm{~m})$ consisted of a reinforced concrete enclosure, containing cooling water distribution piping and spray nozzles. Steam exhausting from the turbine directly above the condenser entered the upper section where non-condensable gases were collected and removed. The inside of the concrete walls was sealed with a 1/8-inch ( $3 \mathrm{~mm}$ ) thick layer of a polymeric compound composed of an epoxy resin and a blend of hard, fine aggregate in order to guarantee that a vacuum condition would be maintained. The top of the condenser was 1'-9" (533 mm) thick, with side walls $2^{\prime}-3^{\prime \prime}(686 \mathrm{~mm})$ thick and the base slab 2"-6" (762 $\mathrm{mm})$ thick. The lined, reinforced concrete provided the required structural strength and had the weight needed to overcome the 
hydrostatic soil pressures caused by the high water table. The body of the condenser was designed to withstand 75 psia (517 KPa).

In our study, BRISC has found it unnecessary to substitute polymer concrete for the materials originally specified.

d. Two-stage steam Jet Ejectors, J-1 and J-2. Noncondensable gases, together with any air that had leaked into the system, were evacuated from the direct-contact condenser by a two-stage steam jet ejector. Both ejector stages were constructed of Type 316L stainless steel. The first had a 20inch $(508 \mathrm{~mm})$ diameter suction and a 16 -foot $(4.88 \mathrm{~m})$ discharge length, and the second a 14inch $(356 \mathrm{~mm})$ diameter suction and an 8-foot $(2.44 \mathrm{~m})$ discharge length. The direct-contact inter-condenser was 8 feet in diameter by 12 feet high $(2.44 \varnothing \times 3.66 \mathrm{~m})$. The direct-contact aftercondenser was 5-foot diameter by 8-foot height $(1.52 \phi \times 2.44 \mathrm{~m})$. Both were of carbon steel with a corrosion allowance of about $3 / 8$ inches $(9 \mathrm{~mm})$.

For the purpose of this study, BRISC has estimated the cost of a comparable system using polymer concrete as a material of construction. Both stainless steel ejectors have been replaced with solid polymer concrete ones. The corrosion allowance in both the inter- and after-condensers has been replaced with solid polymer concrete using a 0.25 inch $(6 \mathrm{~mm})$ minimum carbon steel shell.

e. Hydrogen Sulfide Scrubber, $\mathrm{T}-4$. The hot geothermal brines from the Heber wells were expected to release considerable quantities of carbon dioxide and trace amounts of hydrogen sulfide, methane and ammonia. The hydrogen sulfide concentrations from the plant were expected to be far below toxicity levels, but the odor would be objectionable and the trace amounts released detrimental to vegetation.

Bechtel designed the scrubber to remove a substantial fraction of the hydrogen sulfide from the plant vent gases by scrubbing the gases with blowdown brine from the second-stage flash tanks. The scrubber was a $7^{\prime}-0^{\prime \prime}$ diameter by $16^{\prime}-0$ " (2.13 $\varnothing \mathrm{X}$ $4.88 \mathrm{~m}$ ) vertical vessel. The shell was designed for an operating pressure of 50 psia $(345 \mathrm{KPa})$. Bechtel provided a corrosion allowance of 1.0 inch $(25 \mathrm{~mm}$ ). 
In the BRISC study, a $\frac{1}{4}-$ inch $(6 \mathrm{~mm})$ minimum carbon steel shell is provided, with a minimum $/ 2-i n c h$ ( 13 $\mathrm{mm}$ ) lining of polymer concrete. Packing material, although not specified by Bechtel, is assumed to have been porcelain Raschig rings; no change is made.

f. Piping. All piping exposed to geothermal brine in the Heber plant was designed by Bechtel using carbon steel. A review of Bechtel's carbon steel piping specifications for all size pipes handling brine indicates that their corrosion allowances varied from 0.2 to 0.6 inches ( 5 to $15 \mathrm{~mm}$ ).

For the purposes of this study, BRISC has taken a carbon steel wall thickness of $\frac{1}{4}$ inches $(6 \mathrm{~mm})$ minimum before applying a polymer concrete lining thickness of $\frac{3}{2}$ inch $(13 \mathrm{~mm}$ ) minimum where a possible saving could be effected.

In the Heber plant, the following lines have been investigated for possible savings using polymer concrete linings: 


\begin{tabular}{|c|c|c|c|c|}
\hline & & & & ngth \\
\hline Line Service & Inches & MM & Feet & Meters \\
\hline attery Limits & & & & \\
\hline $\begin{array}{l}\text { Main brine feed line } \\
\text { Branch lines }\end{array}$ & $\begin{array}{l}45 \\
24\end{array}$ & $\begin{array}{r}1143 \\
635\end{array}$ & $\begin{array}{r}715 \\
30\end{array}$ & $\begin{array}{r}217.8 \\
9.14\end{array}$ \\
\hline econd-stage brine & & & & \\
\hline Inlet line & 30 & 762 & 15 & 4.57 \\
\hline $\begin{array}{l}\text { Branch lines } \\
\text { in brine reiniection }\end{array}$ & 24 & 61 & 40 & 12 \\
\hline ine reinject & & & & \\
\hline Line & 40 & 1016 & 715 & 218 \\
\hline $\begin{array}{l}\text { Branch lines } \\
\text { drogen sulfid }\end{array}$ & 20 & 508 & 30 & 9.14 \\
\hline $\begin{array}{l}\text { arogen sult } \\
\text { Line }\end{array}$ & & & & \\
\hline Scrubber return lin & 10 & 25 & & \\
\hline Jet ejector vent line & & & & \\
\hline $\begin{array}{l}\text { stage jet } \\
\text { Inter-condenser to second }\end{array}$ & 20 & 508 & 80 & 24.4 \\
\hline stage jet & 14 & 356 & 10 & 3.05 \\
\hline Vent to scrubber & 14 & 356 & 55 & \\
\hline in circulating water & & & & \\
\hline Distribution line & 60 & 1524 & 80 & 24.4 \\
\hline $\begin{array}{l}\text { ibution line } \\
\text { ibution line }\end{array}$ & 50 & 1270 & 70 & 21 \\
\hline oling line & 10 & & n & 36. \\
\hline jector-condenser coolant & & & & \\
\hline & & & & \\
\hline Main line & 20 & 508 & 20 & 6.09 \\
\hline Branch to inter-condenser & 16 & 40 & 45 & 13 \\
\hline Branch to aft & 10 & 25 & 40 & 12.19 \\
\hline $2 \times \mathbf{i}$ & & & & \\
\hline Fire water lines & 12 & 300 & 1170 & 356 \\
\hline ff-battery limits & & & & \\
\hline & & & & \\
\hline return & 1 & & $\begin{array}{r}7000 \\
32000\end{array}$ & 213 \\
\hline
\end{tabular}




\section{DESCRIPTION OF PLANTS}

\section{NILAND GEOTHERMAL BRINE POWER GENERATION}

\section{PROCESS DESCRIPTION}

The design of the Niland facility was based upon use of a very concentrated brine $(259,600$ ppm T.D.S.). This brine was considered to be supplied by eight wells producing. $460,000 \mathrm{lb} / \mathrm{h}$ ur $(208.6$ tonne/hr) each at 315 psia ( 2172 $\mathrm{KPa})$ and $447^{\circ} \mathrm{F}\left(230^{\circ} \mathrm{C}\right)$ wellhead conditions. The brine gathering and brine reinjection systems were considered to be outside the scope of the Bechtel report. Due to the highly concentrated condition of this brine, the steam which was flashed off in each stage of the plant was condensed and recombined with the brine, so that the brine concentration was essentially unchanged throughout the plant. By this means, the chlorides of sodium, potassium and calcium, principal constituents of the brine, were kept in solution.

In the Bechtel design the hot geothermal brine was assumed to be available at the bottom of the well as thermally saturated water at $550^{\circ} \mathrm{F}\left(288^{\circ} \mathrm{C}\right)$. When brought to the surface and maintained at 315 psia (2172 $\mathrm{KPa})$, steam was flashed from the brine and its temperature thereby reduced so that it entered the plant at $447 \mathrm{O}\left(230^{\circ} \mathrm{C}\right)$. Under these conditions, 158 by weight of the brine was flashed to steam, yielding a steam/ brine mixture which was 6.88 by volume liquid. This mixture entered the Separator/Heat Exchanger, a 10'-0" diameter by 60'-0" (3.05 $\varnothing \times 18.29 \mathrm{~m})$ horizontal vessel, through a 20-inch by $60 \mathrm{ft}(508 \mathrm{~mm} \times 18.29 \mathrm{~m})$ distributor pipe fitted with many orifices. A schematic diagram of the process is shown in Figure III and a section in Figure IV. The greater portion of the separator-heat exchanger was a separating zone where the brine particles dropped out of the steam. The steam rose through a mist eliminator section and then contacted the heat exchanger: tubes, where it gave up its heat to the isopentane motive fluid. The condensate fell back through the mist eliminator, washing it of brine deposited by the steam, and rejoined the main body of brine.

The brine left the separator-heat exchanger and passed to the first stage of the 48-stage Multi-stage Flash Unit. These stages were in four 9'-0" diameter X 60'-0" (2.74 $\varnothing \mathrm{X}$ $18.29 \mathrm{~m})$ compartmented, horizontal vessels as shown in cutaway Figure $V$. In each stage the pressure was lowered from that of the previous stage. The brine passed through an adjustable orifice (pressure drop regulator) and over a weir into the next lower pressure stage. Steam was flashed at each change in pressure, rose through the mist eliminator into the brine. The brine temperature was thus reduced in 48 stages as it passed through the multi-stage 


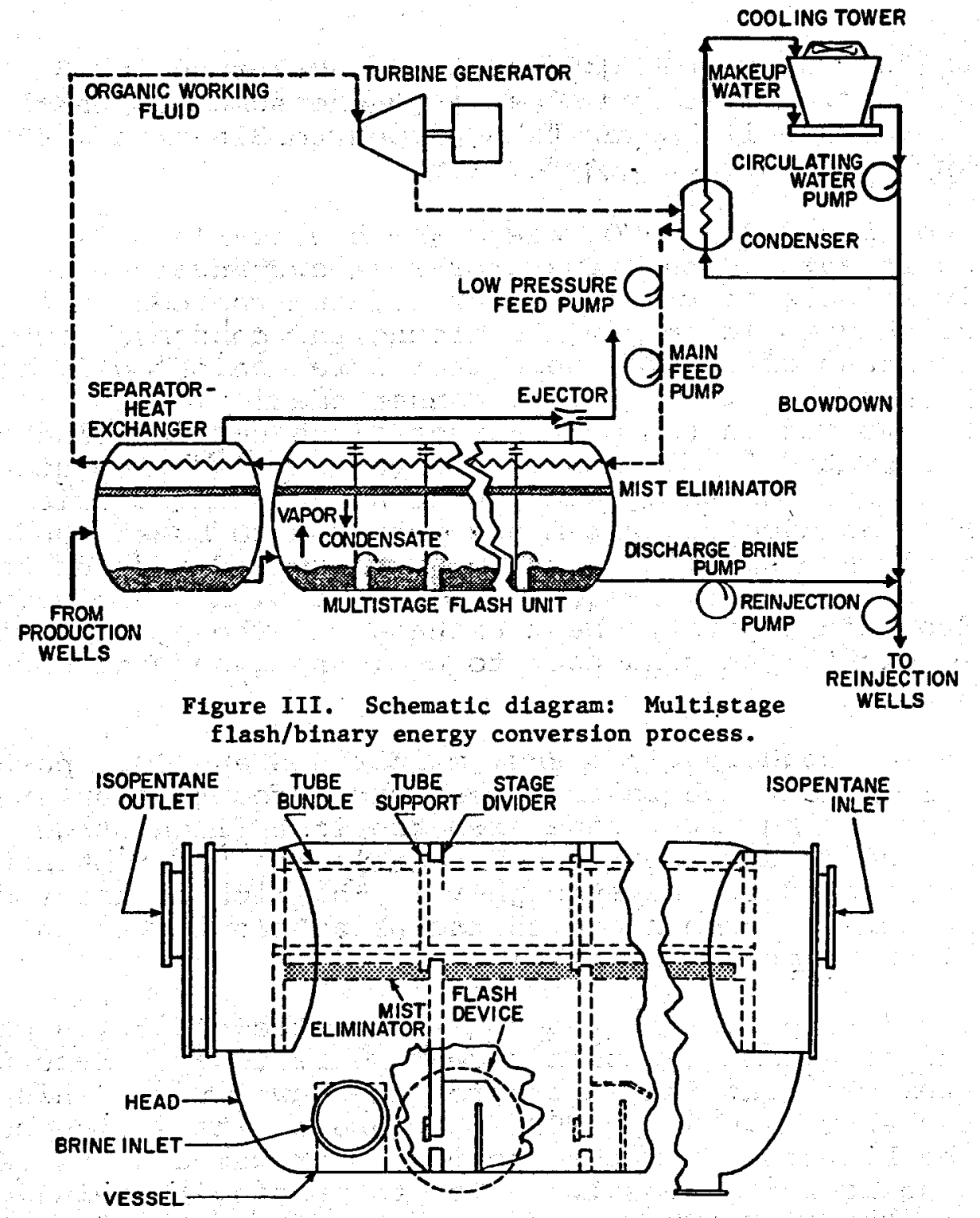

Figure IV. Section view of separator-heat exchanger.

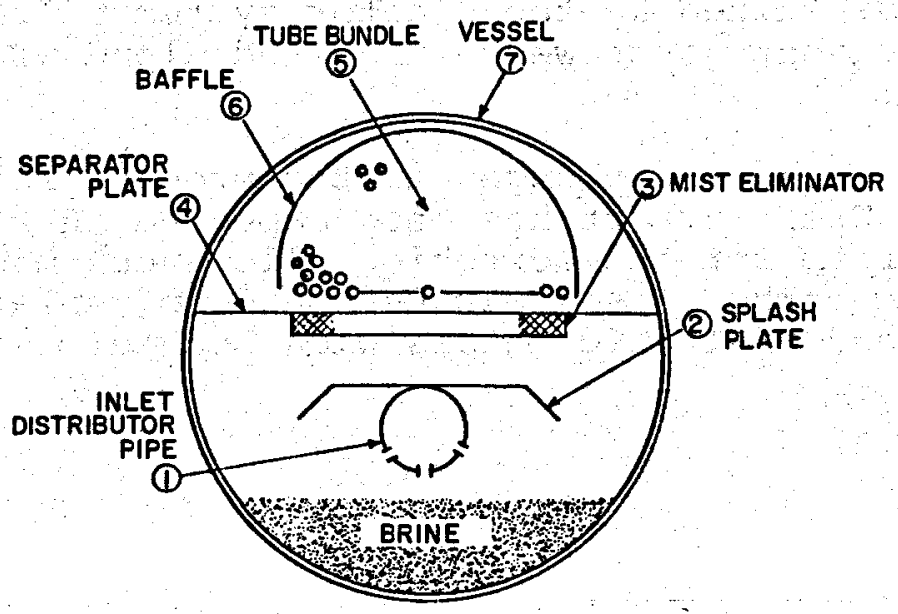

Figure $v$. One unit of multistage flash section. 
flash units. Since the condensate was returned in each stage, the brine left at essentially the same composition as it entered stage 1. It was then pumped to $315 \mathrm{psia}(2172 \mathrm{KPa})$ for reinjection into the formation.

Since the $\mathrm{H}_{2} \mathrm{~S}$ and $\mathrm{CO}_{2}$ gases which were flashed off the brine as it entered the separator-heat exchangers were only slightly soluble in the hot water leaving the condenser section, they would accumulate around the condenser tubes and blind them off. They were therefore continuously vented from the vessel. In a similar manner small amounts of gas would be evolved in the multi-stage flash sections and had to be eliminated. These gases were vented down from stage to stage. In the last stage they were at sub-atmospheric pressure. An ejector system was provided to boost the pressure to atmospheric to allow the non-condensables to be vented. This ejector was powered by the high-pressure vent gases from the separator-heat exchanger. The ejector was provided with a jet condenser to cool the gases and condense the steam.

The non-condensable gases, mainly $\mathrm{H}_{2} \mathrm{~S}$ and $\mathrm{CO}_{2}$, passed to an $\mathrm{H}_{2} \mathrm{~S}$ scrubber where they were subjected to countercurrent ${ }^{2}$ scrubbing with brine from the last flash stage. The brine served to scrub out the $\mathrm{H}_{2} \mathrm{~S}$, allowing the remaining $\mathrm{CO}_{2}$ to be vented to the atmosphere. The rich liquor from the scrubber was combined with the brine flowing to the reinjection pumps for disposal.

Circulating cooling water used for the plant was cooled by an induced-draft, atmospheric-pressure tower. Make-up to the system was brackish water from the New River. This water has about 4,000 ppm TDS. Because of its saline content, the blowdown from the cooling tower was sent to reinjection wells for disposal. Prior to pumping to reinjection pressure, the blowdown was vacuum deaerated with steam to remove oxygen and $\mathrm{CO}_{2}$. The vacuum on the vacuum deaerator vessel was maintained by the ejector system of the flash train and the vent gases were exhausted along with the noncondensables.

BRISC has made no changes in the process flow as set up by Bechtel. Their effort has been expended in substituting polymer concrete for the corrosion allowances made by Bechtel where carbon steel was used and to replacing expensive alloys and/or exotic metals when Bechtel used them. 


\section{EQUIPMENT DESCRIPTION}

a. Separator-Heat Exchange...The separator-heat exchanger, as designed by Bechtel, was a horizontal vessel $10^{\prime}-0^{\prime \prime}$ in diameter and $60^{\prime}-0^{\prime \prime}$ long $(3.05 \varnothing \times 18.29 \mathrm{~m})$. Its shell, of carbon steel, was designed for operation at 350 psia (2413 KPa) and $430 \mathrm{~F}\left(221^{\circ} \mathrm{C}\right)$. The heat exchanger section, located at the top of the shell, as can be seen in cross-section in Figure IV, was composed of 2800 $3 / 4^{n}(19 \mathrm{~mm}) \times 0.035^{\prime \prime}(0.89 \mathrm{~mm})$ wall titanium tubes on a $15 / 16^{\prime \prime}(24 \mathrm{~mm})$ triangular pitch. This required a $4^{\prime}-10^{\prime \prime}(1,473 \mathrm{~mm})$ diameter tube circle. The tubes were 50 feet $(15.24 \mathrm{~m})$ long. The inlet distributor was a 20 -inch $(508 \mathrm{~mm})$ schedule 40 titanium pipe running the length of the separatorheat exchanger. Type $316 \mathrm{~L}$ stainless steel was used for parts subject to erosion. These included the splash plates, separator plates which held the mist eliminator and the baffle surrounding the tube bundle. We have assumed that the tube bundle was fitted with titanium tube spacers, spaced $3^{\prime}-$ $4 "(1.0 \mathrm{~m})$ on centers.

For the purposes of this study BRISC has estimated the cost of a comparable unit using polymer concrete as a material of construction wherever possible. In this design the vessel shell would

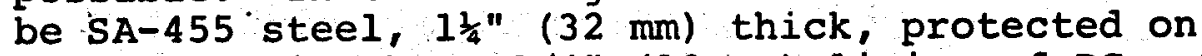
the water side by a $3 / 4^{\prime \prime}(19 \mathrm{~mm})$ lining of PC. In estimating the cost of the Bechtel design we have assumed that the nozzles, manway and other fittings were series 300 to provide a corrosion allowance. - In the BRISC-designed unit these are assumed to be series 150 with a $\frac{1}{2} "$ ( $12 \mathrm{~mm}$ ) PC lining to protect against corrosion. The titanium distributor of the Bechtel design has been replaced by a 20-inch (508 mm) pipe of solid PC, $3 / 4$ " (19 $\mathrm{mm}$ thick, with expanded metal reinforcement. The splash plate, separator plate and baffle around the tube bundle which were specified by Bechtel to be of Type $316 \mathrm{SS}$ have been replaced by similar units of $\mathrm{PC}, 3 / 4^{\prime \prime}(19 \mathrm{~mm})$ thick, reinforced with expanded meta1. The tube support plates of the Bechtel design have been assumed as having been of titanium, $3 / 16^{\prime \prime}(5 \mathrm{~mm})$ minimum thickness to achieve the required rigidity. In the BRISC design these are replaced by $3 / 8^{\prime \prime}(10 \mathrm{~mm})$ thick polymer with cloth reinforcement. These design data have been tabulated for comparison purposes 
in Table III. Many items which are common to the two designs, such as the stainless steel mist eliminator, which do not allow for counterparts fabricated of polymeric materials, are not included in this tabulation, nor have they been included in the cost estimates which follow.

b. Multi-stage Flash Units There were four multistage flash units operating in series. Each unit contained twelve flash sections. A cross-section of a typical section is shown in Figure $V$. The containment vessel was carbon steel, 9'-0" diameter $\times 60^{\prime}-0^{\prime \prime}$ length $(2.74 \phi \times 18.29 \mathrm{~m})$, of $2^{\prime \prime} \mathrm{SA}-$ 455 carbon steel. Degign pressure was 350 psia at $430^{\circ} \mathrm{F}\left(2413 \mathrm{KPa}\right.$ a $\left.221^{\circ} \mathrm{C}\right)$ and full vacuum. The operating pressure varied from 315 psia (2172 KPa) in the first stage to 3 psia $(20.7 \mathrm{KPa})$ in the $48 \mathrm{th}$, Temperatures ranged from $447^{\circ} \mathrm{F}$ to $150^{\circ} \mathrm{F}$ $\left(231^{\circ}-67^{\circ} \mathrm{C}\right)$ in the last section. There was a heat exchange section in each unit consisting of $1800-3 / 4^{\prime \prime}$ OD X $0.035^{\prime \prime}$ wall X 50'. (19. mm $\varnothing \mathrm{X}$ $0.89 \mathrm{~mm} \times 15.24 \mathrm{~m})$. long titanium tubes running through all twelve stages in series. The individual stages were separated by flat steel plate dividers. These are considered to have been reinforced by Ibeam or channel stiffeners to keep the steel thickness of the divider at a minimum. The dividers had an opening near the bottom. This opening was provided with an adjustable weir plate of titanium which could set the size of the opening to give the desired pressure drop between stages. Facing the opening on the downstream side was a weir plate of Type 316SS which formed a pool of Iiquid. The liquid and vapor disengaged as they passed over the weir. There was a titanium splash plate above the weir to reduce liquid carryover into the heat exchanger section.

The multi-stage flash units assumed by BRISC have been designed with shells and heads of $1 \frac{1}{4} "(32 \mathrm{~mm}$ ) thick carbon steel protected on the inside by a 3/4" (19 mm) thick layer of polymer concrete. The inlet and exit nozzles for the brine are series 150 design, protected by a $\frac{1}{2} "$ (13 mm) layer of PC. The stage dividers are assumed to be $3 / 8^{\prime \prime}$ ( $9 \mathrm{~mm}$ ) plates stiffened with channels or I-beams. The divider sheets and stiffeners are designed without corrosion allowance; all surfaces are covered with $\frac{1}{2} "$ ( $13 \mathrm{~mm}$ ) of PC instead. The weir plates, flash devices and adjustable weir plates are designed of $3 / 4 "$ (19 mm) thick polymer concrete reinforced with carbon steel expanded metal: The tube supports are made of cloth-reinforced polymer, $3 / 8$ " (9 mm) 


\section{Table III}

\section{Vessels}

Nlland Plant - Equipment Design Comparison

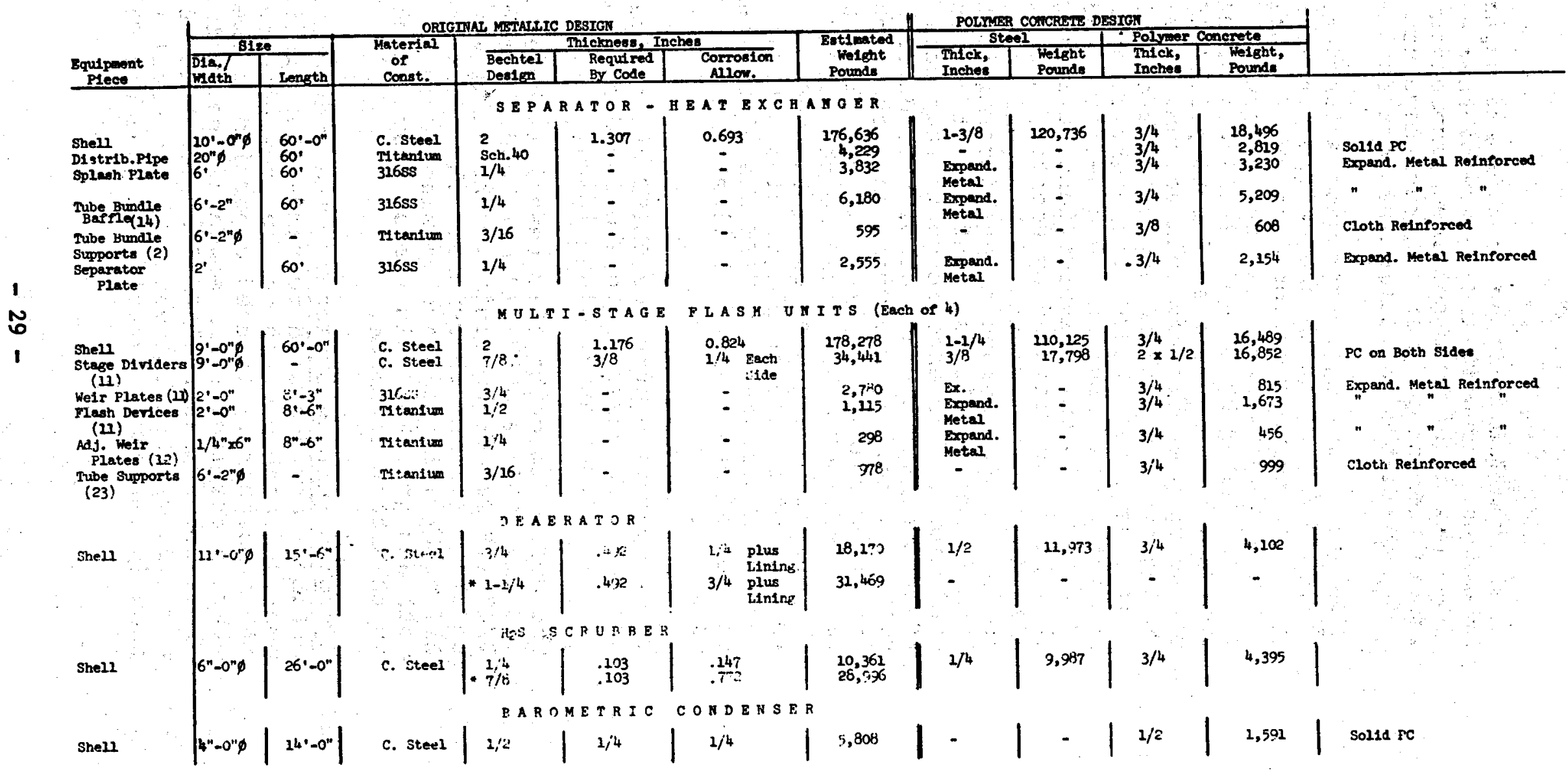

* 3/4" Corrosion Allowance Assumed By PRI.iC 
thick, similar to those used in the separator-heat exchanger. As with the separator-heat exchanger, those parts which do not lend themselves to fabrication of polymer concrete have not been included in the tabulation or cost estimate.

c. Deaerator. The deaerator was designed to remove the oxygen present in the cooling tower blowdown, prior to its reinjection into the formation, by steam stripping under reduced pressure. It was a $7^{\prime}-0$ " diameter by 15'-6" (2.134 $\left.\varnothing \times 4.724 \mathrm{~m}\right)$ vertical vessel designed for $50 \mathrm{psia}$ (345 $\mathrm{KPa}$ ) operating pressure and full vacuum. The internal components and packing supports were of Type 316 stainless steel. There were eight spray nozzles for water distribution and a 6-foot $(1.83 \mathrm{~m})$ bed of 3 inch $(75 \mathrm{~mm})$ polypropylene Pall ring packing. The shell, as designed by Bechtel, was of $\frac{1}{4} "$ ( 6 $\mathrm{mm}$ ) carbon steel coated with a coal tar-epoxy resin. BRISC engineers have determined that a $\frac{1}{4}-$ inch $(6 \mathrm{~mm})$ shell is insufficient for full vacuum conditions. Our experience is that coal tar-epoxy resin coatings are not completely dependable in such service. We recommend that the Bechtel design be changed to $3 / 4 "$ (19 mm) plate plus the resin coating. This would be the 0.492 " ( 12.50 $\mathrm{mm}$ ) thickness required under the code in the absence of stiffener rings, plus a $\frac{1}{4} "$ ( $6 \mathrm{~mm}$ ) corrosion allowance. BRISC has also assumed that the vessel had a $4 !-0 "(1.22 \mathrm{~m})$ skirt of the same material.

For comparative purposes BRISC has estimated the cost of this vessel with shell and head of $3 / 4 "$ (19 mm) carbon steel plus lining.

The BRISC design of this vessel is based upon a $\frac{1}{2}$ " $(13 \mathrm{~mm})$ shell and $\frac{1}{2} "(13 \mathrm{~mm})$ heads protected by 3/4" (19 mm) of PC lining. The skirt would also be of $\frac{1}{2} "$ (13 mm) thickness. The spray nozzles and all other internals are considered to be common to both designs. For this reason they are not included in this cost estimate.

d. Hydrogen sulfide scrubber. The hydrogen sulfide scrubber was designed to remove the $\mathrm{H}_{2} \mathrm{~S}$ from the non-condensable gases before they were released to the atmosphere. It used a portion of the brine leaving the last flash stage as lean solution. The scrubber was a $6^{\prime}-0^{\prime \prime}$ diameter $x 2^{\prime}-0^{\prime \prime}$ ( 1.83 $\phi \times 7.93 \mathrm{~m})$ vertical vessel. The shell was $\frac{1}{4}-$ inch $(6 \mathrm{~mm})$ carbon steel, designed for $50 \mathrm{psia}$ 
(345 KPa) pressure. There was a 4-foot $(1.22 \mathrm{~m})$ bed of $2 \frac{1}{2} "(64 \mathrm{~mm})$ porcelain Raschig rings.

BRISC feels that Bechtel had not provided sufficient corrosion allowance in this vessel. Bechtel allowed $3 / 4 "(19 \mathrm{~mm})$ in the separator-heat exchanger and the multi-stage flash units which were exposed to the same $\mathrm{H}_{2} \mathrm{~S}-\mathrm{CO}_{2}$ mixture. In addition, in the scrubber, there is some $\mathrm{O}_{2}$ present which has been stripped from the cooling tower blowdown. Therefore we believe that this vessel should have been designed with the same $3 / 4 "(19 \mathrm{~mm})$ corrosion allowance as the others mentioned. Therefore the cost of this vessel has been estimated, as an alternate, with $7 / 8$ " (22 $\mathrm{mm})$ shell and heads, which allows $3 / 4 "(19 \mathrm{~mm})$ corrosion allowance.

In the BRISC design the vessel has been designed based upon a $\frac{1}{4} "(6 \mathrm{~mm})$ carbon steel shell lined with $3 / 4 "$ (19 $\mathrm{mm}$ ) of polymer concrete. Since the internals are corrosion-resistant and are common to both designs, no attempt has been made to estimate their cost.

e. Barometric Condenser. This condenser was a direct-contact type with the circulating cooling tower water entering through jets as coolant. The vessel was 4'-0" diameter $\mathrm{X} 14^{\prime}-0 "$ (1.22 $\varnothing \mathrm{X}$ $4.27 \mathrm{~m})$ high. It has been assumed that there was a barometric leg to improve pump suction conditions. For lack of more specific information, it has been assumed that the shell was $\frac{1}{2} "$ ( $13 \mathrm{~mm}$ ) carbon steel, $\frac{3}{4} "(6 \mathrm{~mm})$ of which was the corrosion allowance.

In the BRISC design the barometric condenser shell is made of solid polymer concrete, $\frac{1}{2} "$ ( $13 \mathrm{~mm}$ ) thick. No changes have been made to the jets and internal piping.

In Table II, we have summarized the sizes, materials of construction and estimated weights of the vessels designed by Bechtel and their internal parts which have been deemed capable of being fabricated wholly or partially of polymeric materials for corrosion control. The table also summarizes the equivalent parts, as designed by BRISC, their dimensions and weights.

f. Piping. All piping within the battery limits which was exposed to the brine was designed by 
Bechtel using carbon steel. The main $60 "(1.52 \mathrm{~m})$ circulating cooling water line was designed using 2" $(50 \mathrm{~mm})$ thick concrete pipe. The cooling tower make-up water line, a 16" (406 mm) line, 14,800

feet $(4511 \mathrm{~m})$ long, from the New River was 1" (25 $\mathrm{mm})$ thick concrete. All other water lines were carbon steel.

For purposes of this comparison when BRISC has assumed that a savings may be effected by the use of polymer concrete, lines 14" (356 mm) and over will be constructed of $A-53$, grade $B$ carbon steel of minimum thickness for the pressure, having the steel protected from corrosion by a $\frac{1}{2} n$ (13 mm) layer of PC. This is predicted upon the proven ability of commercial fabricators to line pipes with alumina cement mortars. Iines $12^{\prime \prime}(300 \mathrm{~mm})$ and under are assumed to be fabricated of solid PC. Such pipes have already been prepared at the Brookhaven National Laboratories and are being tested in geothermal brine applications. 
In the Niland plant the following lines are included:

\section{TABLE IV}

Line Service
Brine Inlet
Main Iine
Bypass to Reinjection
Branch Piping
MSF Inlet
USF By-pass
Brine Reinjection
Hydrogen Sulfide
Scrubber Supply
Hydrogen Sulfide
Scrubber Return
Circulating Water Dis-
tribution
Circulating water Dis-
tribution
Circulating Water Dis-
tribution
Ejector-Condenser Cool-
ing Water
Blowdown-Deaeration and
Reinjection
Lube Oil Cooling Water
Firewater

\section{Size $\mathrm{MM}$}

36

$36 \quad 914$

$24 \quad 610$

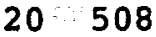

20508

$36 \quad 914$

8200

$8 \quad 200$

601524

501270

$40: 1016$

$8 \quad 200$

8200

$6 \quad 150$

$12 \quad 300$
Length

Feet Meters

$\begin{array}{rr}525 & 1600 \\ 160 & 48.8 \\ 80 & 24.4 \\ 125 & 38.1 \\ 60 & 18.3 \\ 460 & 140.2 \\ 185 & 56.4 \\ 185 & 56.4 \\ 80 & 24.4 \\ 70 & 21.3 \\ 120 & 36.6 \\ 65 & 19.8 \\ 460 & 140.2 \\ 115 & 35.1 \\ 1350 & 411.0\end{array}$




\section{PROCEDURES}

Burns and Roe has not attempted to duplicate Bechtel's effort in the design and cost estimation of the plants. Rather we have estimated the differences in the incremental costs which would be incurred by substituting polymeric materials for those used by Bechtel. Toward this end, no effort has been made to estimate the cost of erection and installation of the equipment since we assume that these costs would be common to both designs. Further, it has been assumed that there would not be any appreciable savings in fabrication labor costs due to the thinner carbon steel shells used in the Burns and Roe design.

In making these comparisons, BRISC engineers calculated the pifimum thickness permitted by the Pressure Vessel Code ${ }^{(4)}$. The cost estimate was then made using the next thicker, commercially available plate of the type steel specified by Bechtel. To this cost was added the cost of polymeric materials and the cost of application. For those parts for which Bechtel used materials other than carbon steel, the cost has been estimated for parts constructed of solid polymer concrete, reinforced with expanded metal where necessary.

The cost of the carbon steel shells and any carbon steel internal structures has been estimated based upon the cost of structural steel as used by Bechtel of $\$ 800$ per ton. This value which was based upon Fall 1975 prices has been corrected to Fall 1977 prices by assuming an escalation of 68 per year. That has yielded a cost of $\$ 800 \times(1.06)^{2}=$ $\$ 898.88$ per ton $(\$ 990.84 /$ tonne). The costs of large diameter carbon' steel pipes used by Bechtel $-20 "$ sch. 20 at $\$ 130$ per lineal foot and $40^{\prime \prime}, 0.500^{\prime \prime}$ wall at $\$ 340$ per lineal foot have been converted to the equivalent $\$ /$ ton, averaged, and escalated in the same manner to yield a cost of $\$ 3651.70$ per ton $(\$ 4,025.25 /$ tonne). The cost of small pipe was likewise estimated, based upon Bechtel's cost of $\$ 15$ per lineal foot for $4^{\prime \prime}$ sch. 40 pipe, as $\$ 3124$ per ton $(\$ 3,443.60 /$ tonne) in 1977.

The cost of polymer concrete is based upon the values assigned by Brookhaven of $\$ 14.95$ per 100 pounds $(\$ 0.330 / \mathrm{kg})$. This is based on laboratory-sized purchases of these materials. Commercial scale quantities should significantly lower this cost figure. The cost of appliçation has been taken as $\$ 5.00$ per square foot $\left(\$ 53.82 / \mathrm{m}^{2}\right)$. 
In applying concrete or similar linings to carbon steel shells it is common industrial practice to weld "Nelson studs" or similar stand-off devices to the shell and then to weld a supporting expanded metal mesh to them. Following this, the concrete is applied by guniting and/or trowelling. We have assumed that a similar procedure would be used in applying polymer concrete. The assumed application cost of $\$ 5.00$ per square foot $\left(\$ 53.82 / \mathrm{m}^{2}\right)$ is based upon past experience in purchase of such linings. It includes the cost of the support materials and their application to the vessel, the cost of the concrete and its application. The $\$ 5.00$ cost used in our estimates is considered to be conservative because we have added the cost of supply of the polymer concrete but have not backed out the cost of the refractory concrete.

Vessel internals in the Bechtel design have been designed of Type 316L stainless steel or of titanium. Burns and Roe has redesigned these in as far as possible, of $3 / 4^{\prime \prime}(19 \mathrm{~mm})$ thick solid PC, reinforced with expanded metal. In the multistage flash units the stage dividers were designed by Bechtel of carbon steel using a $\frac{1}{4} "(6 \mathrm{~mm})$ corrosion allowance. Where the exposure is on both sides, the corrosion allowance must be applied to each side. We have assumed that Bechtel designed these with a minimum plate thickness of $7 / 8^{\prime \prime}(22 \mathrm{~mm})$ and used channels or I-beams to reinforce the flat plates to achieve the necessary strength. In the Burns and Roe design 3/8" (9 mm) thick plates were used with both sides and all exposed surfaces of the reinforcing channels or I-beams being covered with $\frac{1}{2} "(13 \mathrm{~mm})$ of polymer concrete.

The cost of carbon steel in these applications has been assumed to be the same $\$ 800$ per ton, escalated for two years at 68 or $\$ 898.88$ per ton $(\$ 990.84 /$ tonne). Polymer concrete was estimated at $\$ 14.50$ per $1001 \mathrm{bs}$. $(\$ 0.330 / \mathrm{kg})$ and the cost of applying it at $\$ 5.00$ per square foot $\left(\$ 53.82 / \mathrm{m}^{2}\right)$. The cost of Type 316L stainless steel was estimated as being four times the cost of carbon steel or $\$ 3595.50$ per ton $(\$ 3,963.32 /$ tonne). Similarly, titanium was estimated as being 25 times as expensive as carbon steel or $\$ 22,472$ per ton $(\$ 24,771 /$ tonne $)$.

The major lines which were designed of carbon steel by Bechtel were designed with varying amounts of corrosion allowance. The sizes and length of these lines, the corrosion allowance, the weight per foot and total weight of each has been tabulated in Tables II and IV. Bechtel included three cost figures for these pipes in their report. Two sizes of large diameter lines were given; 20 " schedule 20 at $\$ 130$ per lineal foot and $40^{\prime \prime}, 0.500^{\prime \prime}$ wall at $\$ 340$ per 
lineal foot. These were reduced to a dollars per ton basis, averaged and escalated to 1977 to give a value of $\$ 3651.70$ per ton $(\$ 4,025.27 /$ tonne $)$. The cost of a $4 "$ schedule 40 carbon steel pipe was given as $\$ 15$ per lineal foot. This has been subjected to the same escalation rate of $6 \%$ per year. Other line sizes 12" $(300 \mathrm{~mm})$ and below have been estimated by ratioing this value on a pounds/foot basis ( $\$ 3124 /$ ton, $\$ 3444.60 /$ tonne).

To estimate the cost of large lines lined with PC, the cost of the minimum thijkness steel pipe has been estimated according to the code ${ }^{4)}$. To this we added the cost of the PC material at $\$ 14.50$ per 100 lbs. $(\$ 0.330 / \mathrm{kg})$ using a PC thickness of one-half inch $(13 \mathrm{~mm})$. We have also added a cost of $\$ 5.00$ per lineal foot for application. This value was obtained by conversations with firms which regularly apply Portland cement concrete to existing steel pipe lines.

Lines 12" ( $300 \mathrm{~mm})$ and under have been considered to be fabricated of solid PC in a manner similar to that used in preparing samples which are presently being field tested. The cost of these has been assumed to be $\$ 5.00$ per foot $(\$ 16.40 / \mathrm{m})$ for sizes $4 ", 6 "$, and $8 "(100,150$ and $200 \mathrm{~mm})$ and $\$ 7.50$ per foot $(\$ 24.60 / \mathrm{m})$ for size $12 "(300 \mathrm{~mm})$. These figures are assumed to cover materials and labor. 


\section{RESULTS OF STUDY}

The potential economics in the operation of geothermal energy plants are dependent on two factors - the initial installed cost of the plant and the operating cost. In this study we have estimated the savings in capital investment which may be obtained by the substitution of polymer concrete for a corrosion allowance for carbon steel parts or the use of expensive alloys or metals. At the present time, tests are under way to prove that polymer concrete has a life expectancy under flowing conditions comparable to the superior life qualities which it has shown under static laboratory and preliminary flowing field test conditions.

Since geothermal energy plants have not yet operated on the waters studied in this report, any assumptions concerning service life of the materials of construction and the downtime which may be expected for repairs of plants designed to use them is purely academic. For the purposes of this report we have assumed that the polymer concrete will have a service life at least as long as that of the materials which it is replacing.

The costs of the original metallic design carried out by Bechtel and the polymer concrete design by BRISC have been estimated based upon the weights of steel, alloys and polymer concrete employed. The unit costs of each of these materials has been derived as detailed under Procedure, p. 35. It has been emphasized that the costs which have been obtained are differential costs and not absolute costs, as many items which are common to both designs have been omitted. Differential costs are accurate in determining the capital cost savings which may be effected through the use of polymer concrete materials.

\section{HEBER PLANT}

The weight of carbon steel, alloy steel and exotic metals used in each of the major pieces of equipment designed by Bechtel has been estimated in this manner. The same was done for the main pipe lines within the battery limits and for the off-battery limits lines which were detailed by Bechtel.

The results of this study have been tabulated in Tables $V$ for equipment within the battery limits and VI for piping inside and outside the plant battery limits.

The cost savings to be realized by using, where possible, polymer concrete lining to replace some of Bechtel's corrosion allowances for both equipment and lines in the Heber conceptual plant are listed in these tables. 
Table V

HEBER, Calif. Geothermal Plant

Vessel \& Equipment Cost Savinga

Originel Metallic Desion

Polver concreta Dealen

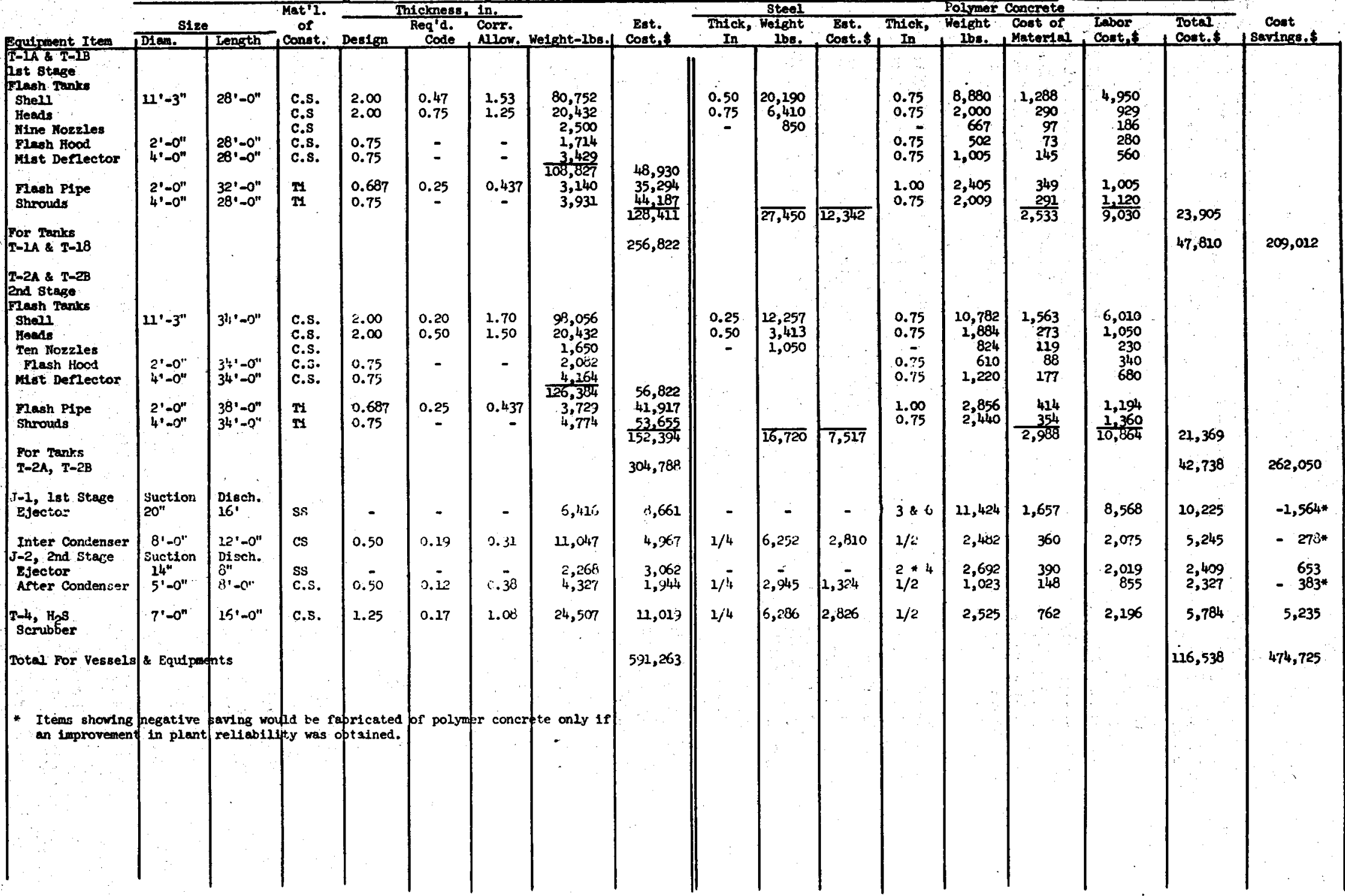


Table VI

Piping

HEBER, Calif., Geothermal Plant - Cost Savings

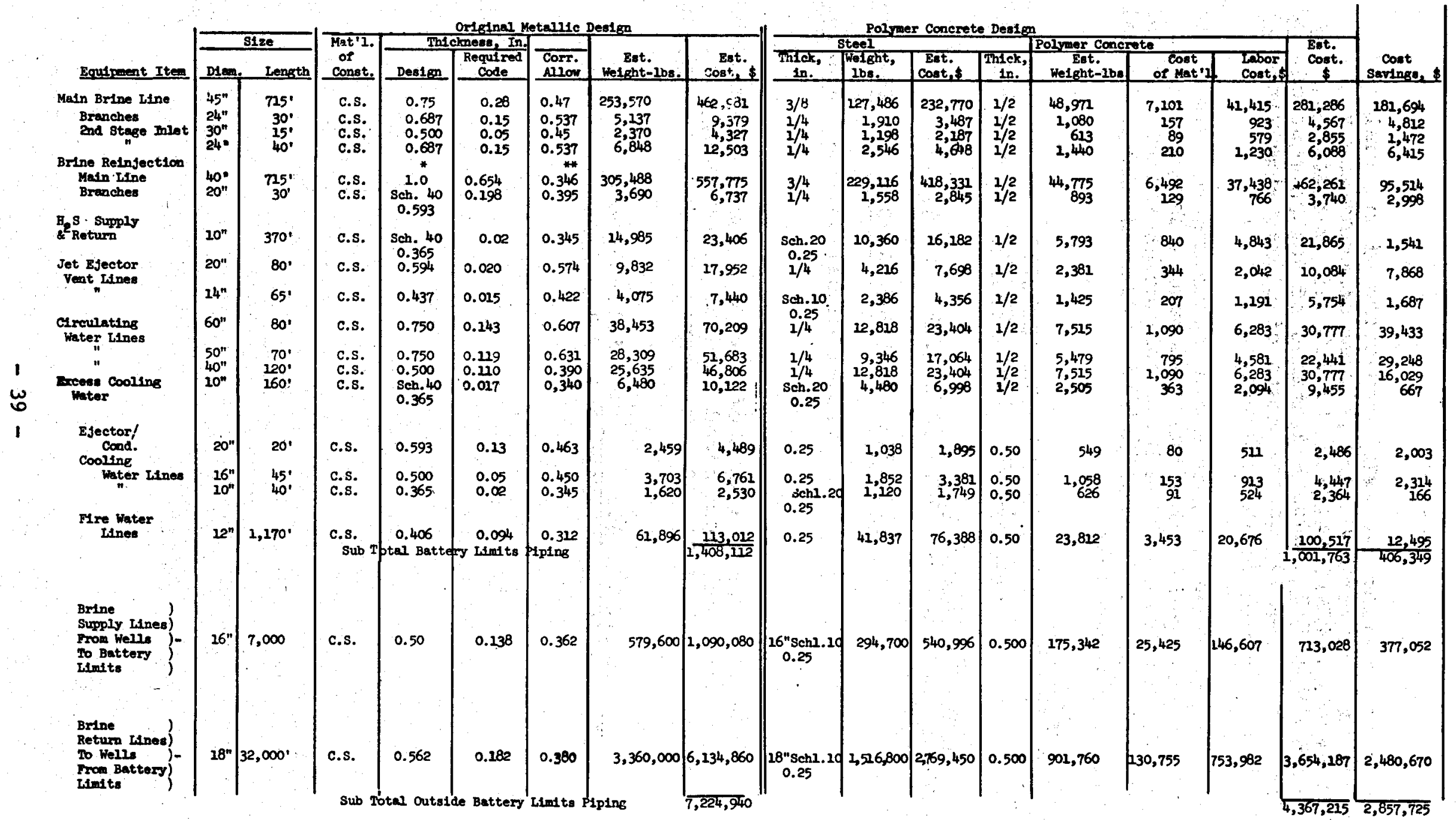

- Adjusted by BRISC

* Applied by BRIsC 
When comparing the estimated costs of the original design with the costs of the polymer concrete design, a total capital cost savings of $\$ 3,738,799$ is obtained. As shown in Table VII, major reductions of $80 \%$ in the cost of vessels and 29 to 408 in the costs of piping resulted with the use of polymer concrete linings.

Based on Bechtel's levelized annual capital cost rate of 178 for the plant investment assuming a 30-year plant life, 178 for 30-year life brine production wells, and 258 for 10-year life brine reinjection wells, the total annual savings are as follows:

Battery Limits: Equipment

Outside Battery Limits:

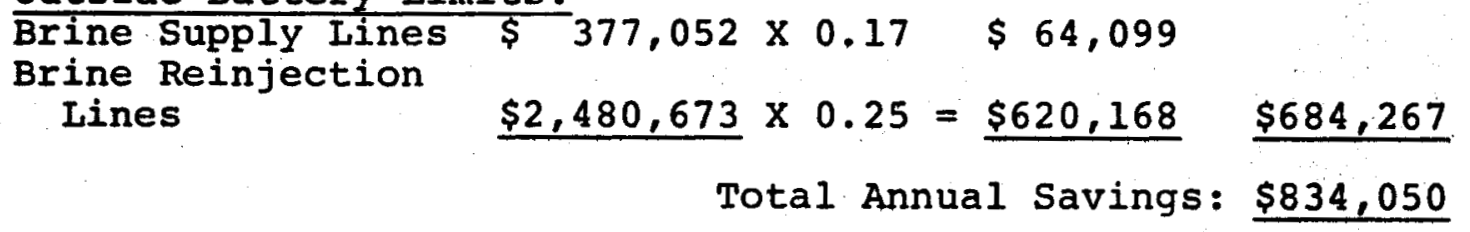

The savings in the cost of power produced by the Heber plant may be calculated, based upon the estimated total annual savings of $\$ 834,050$. The savings in power cost would be:

$$
\begin{array}{ll}
\$ 834,050 & =\$ 0,00272 / \mathrm{Kwh} \\
50,000 \times 0.7 \times 8760 & =2.72 \mathrm{mills} / \mathrm{Kwh}
\end{array}
$$


TABLE VII

SAVINGS WITH POLYMER CONCRETE

ORIGINAL

METAL

\section{Battery Limits}

\section{Equipment}

Flash Tanks $\$ 561,610$

Ejectors Con-

densers

18,634

Vent scrubber

11,019

Sub total

\$ 591,263

Lines

Total B.L.

$\frac{1,408,112}{\$ 1,999,375}$

Outside Battery

Limits

Brine Supply Lines

Brine Reinjection Lines

Total O.B.L.

$$
\begin{array}{r}
\$ 1,090,080 \\
6,134,860 \\
7,224,940
\end{array}
$$

$\$ 9,224,315$
POLYMER

CONCRETE

$\$ 90,548$

20,206

5,784

$\$ \quad 116,538$

$\frac{1,001,763}{1,118,301}$

$\$ 713,028$

$3,654,187$

$4,367,215$

$\$ 5,485,516$
SAVINGS

$\$ 471,062$

$$
-1,572
$$

5,235

$\$ 474,725$

$\frac{406,349}{881,074}$

83.9

$-8.4$

47.5

80.3

$\frac{28.9}{44.1}$

$\$ 377,052$

34.6

$2,480,673$

$2,857,725$

$\underline{40.4}$

39.6

$\$ 3,738,799$ 


\section{NILAND PLANT}

A similar case can be built for the Niland plant. In the Niland case Bechtel gave no estimated costs for portions of the plant lying outside the battery limits. The greatest savings in the Heber plant estimate were effected in that area. A similar saving would undoubtedly show for Niland if the data were available.

The cost savings for Niland within the battery limits, when calculated in the same manner as those of the Heber plant, are listed in Tables VIII, IX and $X$. Total savings of $\$ 553,741$ were realized through the use of polymer concrete linings. Vessel and equipment costs were reduced by 468 and piping costs by 268 .

Based on Bechtel's levelized annual capital rate of $17 \%$ for the plant investment assuming a 30 -year plant life, the annual savings are:

Equipment $\quad 317,888 \times 0.17=\$ 54,041$

Lines

$$
235,853 \times 0.17=\frac{40,095}{594,136}
$$

Total Annual Savings: $\overline{\$ 94,136}$

The savings within the Niland plant are not great enough to affect the cost of power generation appreciably:

$$
\frac{\$ 94,136}{50,000 \times 0.7 \times 8760} \times 1,000=0.31 \mathrm{mills} / \mathrm{Kwhour}
$$

However, we must point out that the savings shown for the Heber plant were mostly effected in the off-site facilities. These facilities would show a similar savings possible for the Niland operation if the data were made available by Bechtel.

\section{Cost of Electrical Energy}

Bechtel in their report estimated the incremental cost of electrical energy (COEE) by a formula which takes into account the capital investment cost and the annualized operating and maintenance costs. The capital investment cost includes the construction cost, Owner's cost during construction and interest on capital during construction. The interest cost is estimated as being 8 percent per year of the capital cost for the last third of the construction period. The formula used and estimated cost based on Bechtel's estimated cost figures are:

$$
\text { COEE }=\frac{\text { (Cap. X LACC) }+(O \& M) \text { plant }+(\text { Cap. X LACC) }+ \text { O\&M WeIls }}{K_{\mathrm{E}} \mathrm{XCF} \times 8760}
$$


Table VIII

Vessels

Niland - Equipment - Cost Estimate

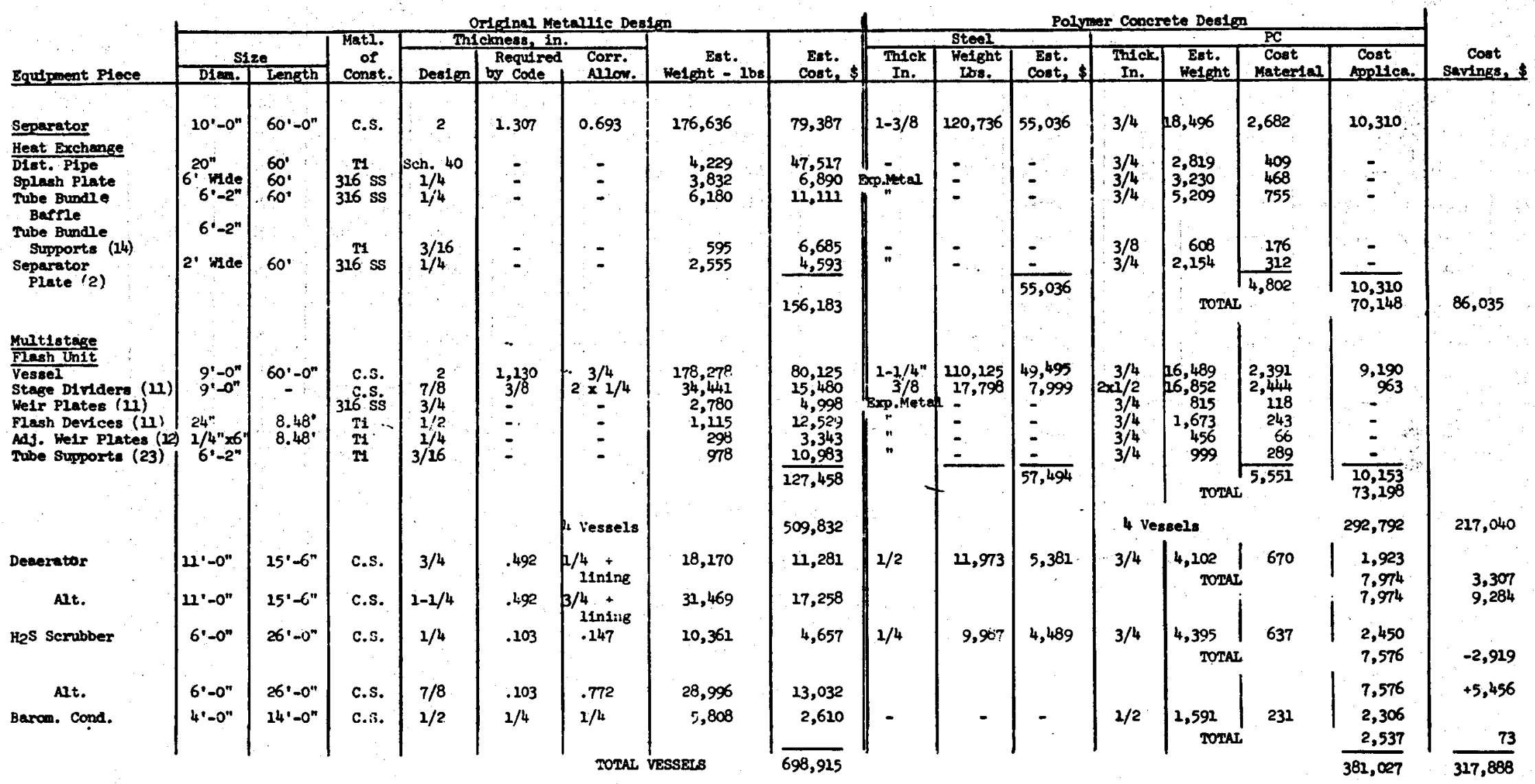

NOTE: Costs, Etc. In this tabulation are for comparative purposes only. They do not include many items which are comman to both designs. 
Table IX

Lines

Niland - Equipment - Cost Estimate

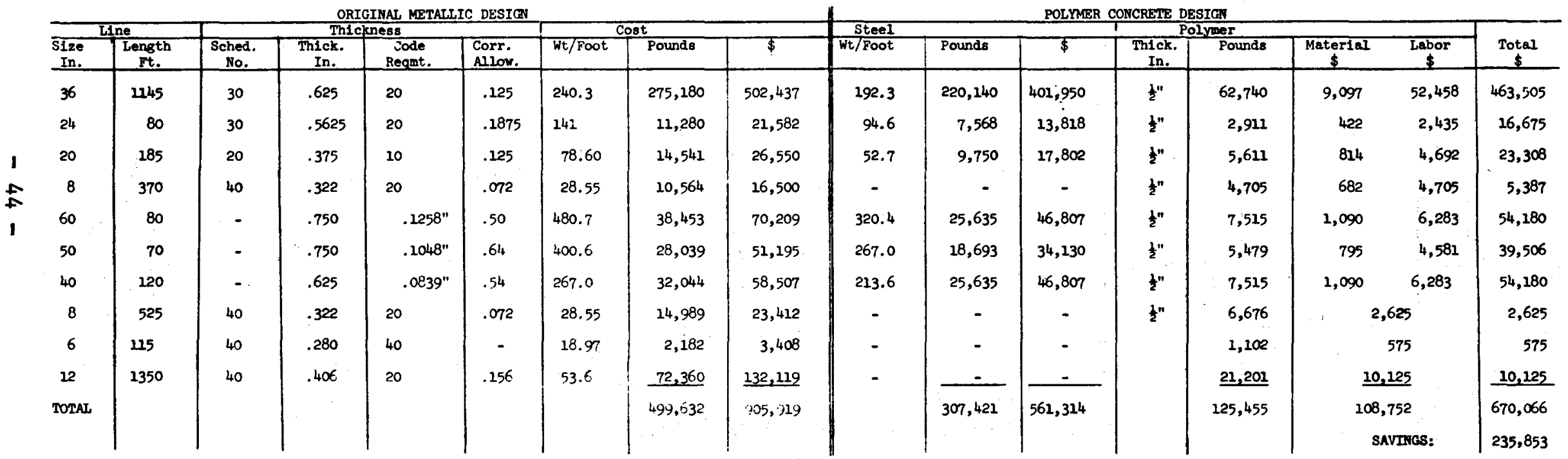

Based on pipe costs estimated by Bechtel, P II 9-2 
TABLE X

NILAND PLANT

\begin{tabular}{|c|c|c|c|c|}
\hline Battery Limits & $\begin{array}{l}\text { Original } \\
\text { Metallic }\end{array}$ & $\begin{array}{l}\text { Polymer } \\
\text { Concrete }\end{array}$ & Savings & $\begin{array}{l}8 \text { Reduction } \\
\text { or Savings }\end{array}$ \\
\hline $\begin{array}{l}\text { Equipment } \\
\text { Lines } \\
\text { Total }\end{array}$ & $\begin{array}{r}\$ \quad 698,915 \\
905,919 \\
1,604,834\end{array}$ & $\begin{array}{r}381,027 \\
670,066 \\
\$ 1,051,093\end{array}$ & $\begin{array}{r}\$ 317,888 \\
235,853 \\
\$ 553,741\end{array}$ & $\begin{array}{l}45.5 \\
26.0 \\
34.5\end{array}$ \\
\hline
\end{tabular}

From Bechtel:

$$
\begin{aligned}
& \text { Capital cost Plant } \\
& +88 \text { Owner's cost } \\
& \$ 37.2 \times 10^{6} \\
& 2.976 \\
& ++88 / \text { year for } 1 / 3 \times \frac{40}{12} \mathrm{yr} \text {. } \\
& \text { IACC } 178 \text { for } 30 y r \text { life } \\
& \frac{3.3067}{\$ 43.4827} \times 10^{6} \\
& \text { O\&M at } 48 \text { of const. cost } \\
& 7.39205 \\
& 1.73931 \\
& \frac{1.73931}{\$ 9.13136} \times 10^{6} \\
& \text { Capital cost } 28 \text { prod. wells at } \$ 400 \mathrm{~K} \\
& \text { Piping from field } \\
& \$ 11.2 \times 10^{6} \\
& 7.420 \\
& \$ 18.620 \times 10^{6} \\
& \text { Owner's cost at } 108 \\
& \frac{1.862}{20.482} \times 10^{6} \\
& \text { LACC }=178 \text { per } 30-y \text { r life } \\
& 3.48194 \times 10^{6} \\
& \text { Capital cost } 14 \text { reinject. at } \$ 400 \mathrm{~K} \\
& \text { Treatment plant } \\
& \$ 5.6 \times 10^{6} \\
& \frac{2.0}{7.6} \times 10^{6} \\
& \text { Owner's cost at } 108 \\
& \frac{.76}{8.36} \times 10^{6} \\
& \text { LACC }=25 \% \text { for 10-year life } \\
& 2.09 \times 10^{6} \\
& \text { (O\&M) prod. 208.2 } 20.482= \\
& 4.09640 \times 10^{6} \\
& { }^{(O \& M)_{\text {Reinn }} 108 \cdot 1 \times 8.36=}= \\
& \$ \frac{.8360}{19.6357} \times 10^{6} \\
& \operatorname{COEE}=\frac{19.6357 \times 10^{6}}{50,000 \times 0.7 \times 9760}=\$ .06404 \quad 64.04 \mathrm{mi11s}
\end{aligned}
$$


Plant availability, expressed as the percentage of a year the plant is able to generate power at full rated capacity and is not out of service for either scheduled or forced maintenance, can be increased by improving the reliability or service life of critical components.

As far as polymer concrete linings are concerned, the flash tanks, brine supply and reinjection lines, scrubbers and condensers are of immediate importance. Polymer concretes will reduce maintenance requirements and result in improved on-stream factors.

Bechtel estimates, for their Heber conceptual plant, an approximate 708 availability. Good operating conditions for power plants dictates $80 \%$ reliability as satisfactory

Iining of flash tanks in the Heber plant will, we believe, result in at least a 18 increase in plant availability. It is to be noted that this level of improvement (18) was identified in the Bechtel report as a program goal resulting from anticipated research and development programs. It appears that the original goal can be met with the successful application of polymer concretes.

Corrosion in carbon steel piping has been a major contribution to high maintenance cost and plant repairs in saline environments. The use of polymer concrete lined pipe in the Heber plant will, we believe, eliminate major problems with corrosion and result in an estimated 38 increase in plant availability.

The estimated increase of $4 \%$ in availability will result in a total net reduction in power costs of $3.46 \mathrm{mills}$ per kilowatt hour, based upon Bechtel's investment costs, when calculated as done earlier. If the availability is increased from 708 to 748 :

COEE at $748=\frac{\$ 19,6357 \times 10^{6}}{50,000 \times 0.74 \times 8760}=60.58 \mathrm{mills} / \mathrm{kwh}$

COEE at $708=\frac{\$ 19.6357 \times 10^{6}}{50,000 \times 0.7 \times 8760}=64.04$

$$
\text { Saving: } \quad 3.46
$$

The estimated reduction in capital costs and improved operatings experience through the use of polymer concrete would thus effect an overall savings of $6.18 \mathrm{mills}$ per kilowatt hour for the Heber plant. A similar savings for the Niland plant appears certain. 


\section{REFERENCES}

1. Conceptual Design of Commercial 50 MWe (net) Geothermal Power Plants at Heber and Niland, California, October 1976, Energy Research and Development Administration, Division of Geothermal Energy, SAN-1124-1.

2. Alternate Materials of Construction for Geothermal Applications, Progress Report No. 11, October-December, 1976.

3. Progress Report No. 12, January-March, 1977. Process Technology Division, Department of Applied Science, Brookhaven National Laboratories Concrete-Polymer Materials for Geothermal Applications

Progress Report No. 6 - July-September, 1975

Progress Report No. 7 - October-December, 1975 Radiation Division, Department of Applied Science, Brookhaven National Laboratory.

4. ASME Boiler and Pressure Vessel Code, Section VIII, Division 1, Pressure Vessels, 1977 Edition ANSI/ASME BPV-VIII-1

5. Cementing of Geothermal Wells, Progress Report No. 3, October-December 1976, Progress Report No. 4, JanuaryMarch 1977, Brookhaven National Laboratory Associated University, Inc.

6. Concrete-Polymer Materials

Second Topical Report - December, 1969

Third Topical Report - January, 1971

Fourth Topical Report - January, 1972

Fifth Topical Report - December, 1973

Radiation Division, Department of Applied Science, Brookhaven National Laboratory Associated University, Inc. 